Portland State University

PDXScholar

Dissertations and Theses

Dissertations and Theses

5-1-1969

\title{
An analysis of children's drawings of policemen
}

Jess A. Armas

Portland State University

Linda L. Simonitch

Follow this and additional works at: https://pdxscholar.library.pdx.edu/open_access_etds

Let us know how access to this document benefits you.

\section{Recommended Citation}

Armas, Jess A. and Simonitch, Linda L., "An analysis of children's drawings of policemen" (1969).

Dissertations and Theses. Paper 885.

https://doi.org/10.15760/etd.885

This Thesis is brought to you for free and open access. It has been accepted for inclusion in Dissertations and Theses by an authorized administrator of PDXScholar. Please contact us if we can make this document more accessible: pdxscholar@pdx.edu. 
AN ABSTRACT OF THE THESIS OF Jess A. Armas and Innda L. Simonitch for the Master's Degree in Social Work presented on May 5, 1969.

Title: An Analysis of Children's Drawings of Policemen.

APPROVED BY WEMEERS OF THE THESIS COMMTTEE:

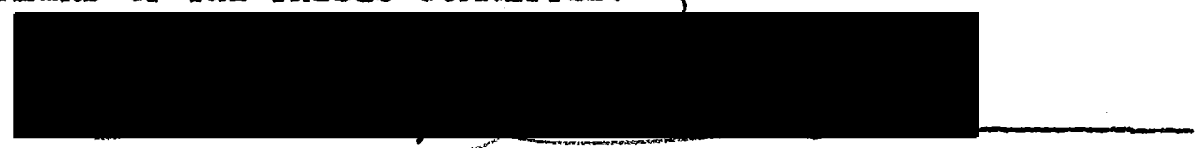

Frank F. Miles, Chairman

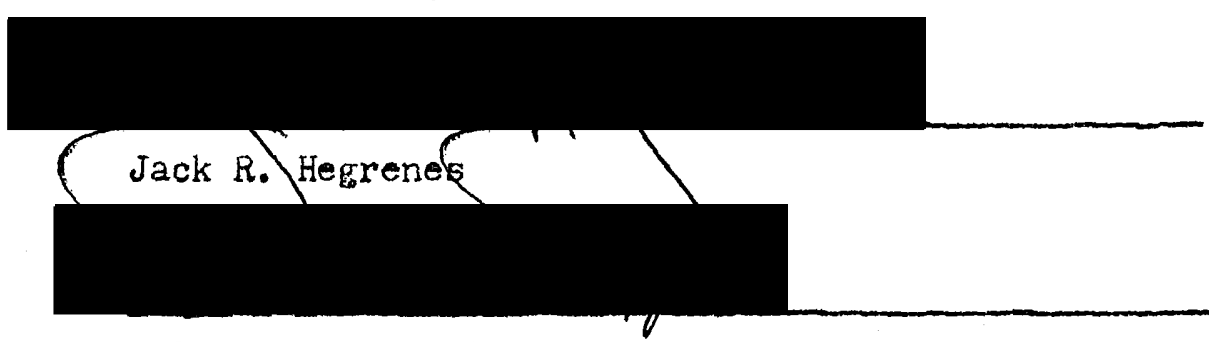

Walter Nunokawa

The overall objectives of this study had a dual focus. One was to determine the attitudes of cilildren toward police from projective drawings. The second utilized the experience of performing the first objective to assess the possible adaptation and use of projective techniques in social work.

One hundred and twenty-nine children from three different Portland public schools were given the topic "I met a policeman in my neighborhood" and asked to draw a picture. Second graders in an upper white socioeconomic school, a lower white socioeconomic school, and a school in a lower socioeconomic Negro area wero compared.

It was expected that the Negro children's drawings of policemen would indicate more negative feelings than the drawings from elther a similar socioeconomic group of white children or a higher socioeconomic 
group of white children. The lower socioeconomic white children's drawings of policomen wore expected to show more negative feelings than the drawings of the upper socioeconomic whit group. To test the overall study hypothesis eight hypotheses were developed. These hypotheses were tested through eight judgment categories: distance between self and policeman, ratio of hoight of self to height of policeman, height of policeman, omitted body parts of policeman, large hands of policeman, number of weapons, and obvious aggression by policeman.

Each picture was judged independently and blind by two judges. A third judge was used in cases of disagreement. Judgment agreement was 2bove $95 \%$ for all eight categories. Resulting judgments for the three groups wore compared on 211 eight items through chi square and median tests. A composite score for each picture consisting of the total number of the eight categories judged to be negative was then used to test the overall hypothesis.

Comparison of the three groups on the individual categories yielded mixed results. The upper white group was significantly less negative than both other groups on the omissions item, and less negative than the lower socioeconomic Negro group on the height and smile items. Differences between the lower white and lower Negro socioeconomic groups and between the upper and lower white groups were inconclusive. The lower white group was more negative than the other groups on the omissions and less negative on the weapons items. These differences were not in the predicted direction.

Testing of the overall hypothesis showed the upper whit socioeconomic group less nagative in their attitudes toward policemen than - ither the lower white or the lower Negro socioeconomic groups. There was no significant difference between the lower white and lower Negro 
socioeconomic groups. The study would suggest, then, that the upper socioeconomic white children have less negative attitudes toward policemen than either of the other two groups. This difference seems to be more socioeconomic than racial, since the Negro children's drawings should have showed more negative attitudes than the whit children of the same socioeconomic status if determinants were primarily racial.

It was possible in this study for social workers to have high judgment agreement, but only by utilizing simplified and very concrete judgment criteria. Nuch skill and training are required for social workers to utilize the projectivos. In addition, validity is difficult to determine, and interpretation of data using projective techniques can be uncertain and ambiguous. Given these limitations, tho utilization of projective methods by social workers should be undertaken with caution. 
AN ANALYSIS OF CHILUREN'S DRAWINGS OF POLICENGN

\section{by}

JESS A. ARMAS AND LINDA L. SIMONITCH

A thesis submitted in partial fulfillment of the requirements for the degree of

MASTER OF SOCIAL WORK

Portland State University 1969 
TO THE OFFICE OF GRADUATE STUDIES:

The members of the Committee approve the thesis of

Jess A. Armas and Linda L. Simonitch presented on May 5, 1969.

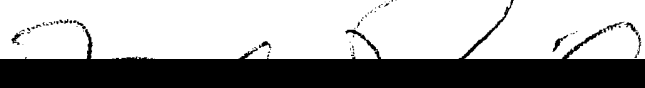

Frank F. Miles, Chairman
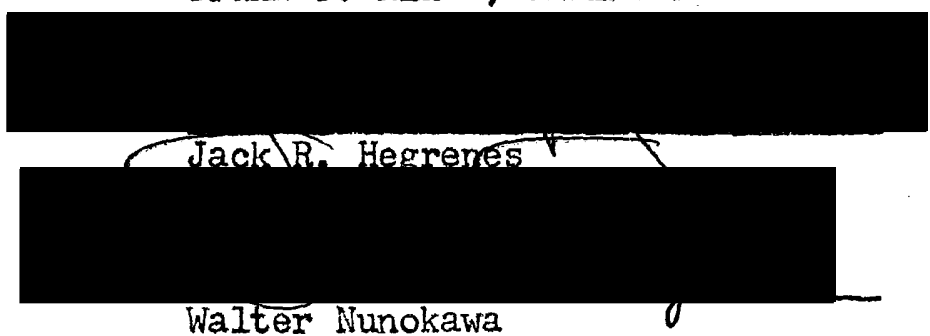

APPROVED:

Daniel E. JennIngs, Acting Dean, School of Social Work Lavid R. Malcolm, Acting Dean of Graduate Studies May 5,1969 


\section{ACKNOWLEDGNENTS}

We wish to thank the Principals of Ainsworth, Buckman, and Humboldt schools, Joseph C. Hartley, Richard H. Wheatley, and Herbert H. Hale for their cooperation in obtaining pictures. Without the help and the participation of Principals, second grade teachers, and pupils of these three schools this study would not have been possible. We would further like to express our appreciation to the members of our thesis committee, Jack Hegrenes, Dr. Frank Miles, and Dr. Walter Nunokawa for their guidance and suggestions. 
TABLE OF CONTENTS

PAGE

ACKNOWLEDGIENTS . . . . . . . . . . . . . .

LIST OF TABLES ...................

vi

CHAPTER

I. INTRODUCTION

The Problem .................. 3

General Approach ........... ?

II. NETHODOLOGY

Rationale ................... 11

subjects .................. 12

Data Collection .................. 13

Analysis of Pictures .......... 14

Statistical Procedures ......... 17

III. FINDINGS ........................ 18

Tests of Hypotheses ............. 18

Judgment Agreement .............. 30

Analysis of Sexual and Age Differences . . . 32

Analysis of Items Nine through Twelve ..... 34

Conclusions and Implications for Further

Research ................. 38

BIELIOGRAPHY ....................... . . . . 43

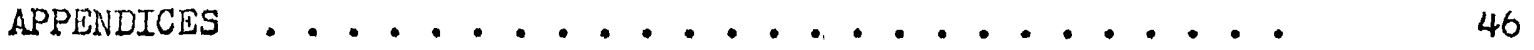


APPENDIX A

APPENDIX B 48 APPENDIX C 


\section{LIST OF TABLES}

TABLE

PAGE

I. Responses of $120 \mathrm{Kalamaz00}$ and 150 Grand Rapids Police

Officers to: "Do the Inner City Youth Feel the

Police Are Always Picking on Negroes?" . . . . . 4

II. Responses of $120 \mathrm{KalamazoO}$ and $150 \mathrm{Grand}$ Rapids Police

Officers to: "Do the Inner City Youth Think That

the Police Are Unfair in Their Treatment of

Different Races, Nationalities, and Religious

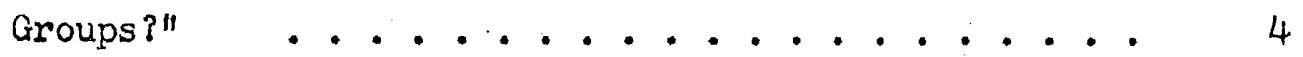

III. Tests of Hypotheses Comparing Group B and Group C ... 19

IV. Tests of Hypotheses Comparing Group A and Group B . . . 19

V. Tests of Hypotheses Comparing Group A and Group C . . 20

VI. Percentage Distribution of Three Groups by Number of

Negative Indicators in Pictures $\ldots . . . .28$

VII. Comparison of Items by Sex for Group A . . . . . . 33

VIII. Comparison of Items by Sex for Group B . . . . . . . 33

IX. Comparison of Items by Sex for Group C . . . . . . 34

X. Number of Colors Used in Picture Out of Maximum of

Seven ............................. 36

XI. Quality of Drawings . . . . . . . . . . . 37

XII. Judgrent Agreements for Items 9-12 .......... 3 ? 


\section{CHAPTER I}

\section{INTRODUCTION}

The profession of social work is in a period of reexamination. Recent professional journals have questioned social work's relevance to present social problems $(2,2)$. Changes have been suggested in values, theories, and techniques. In response, advocates of the socio-behavioral theory (3) and general systems theory (4) have examined other social sciences for knowledge to enhance social work practice. The pur pose of this study is to examine the use of drawings as a projective technique by social workers in a socially relevant context.

Psychology has used art both as a means of personal assessmont and as a data collecting technique for research $(5,6)$. Reviews of this literature are available $(7,8,9)$. However, it is not the intention of this study to assess and evaluate techniques as used by psychologists but rather to determine if the techniques can be adapted for use in social work.

The rationale for such a study is based on Gordon's (10, p.9) statement of the position of social work in relation to psychology and sociology.

The central focus of social work traditionally seems to have been on the person-in-his-life-situation complex--a simultaneous dual focus on man and environment. This focus has been unbalanced at times on the side of the organism under the impact of psychological theory and then on the side of environment under the impact of sociological and economic theory. The main stream of social work, however, has bocome neither an applied psychology nor an applied sociology. 
This study attempts to retain the "simultaneous dual focus" by using personality assessment methods on groups to assess environmental influences. Koppitz and de Moreau (II) used this method to validate cultural differences in Mexican and American childron. Their methodology was not used, but the principle of obtaining information about environmental or cultural attitudes by projectivo drawings was accepted. The need to have knowledge of the environment for social workers to understand "the person-in-his-life situation" was considered sufficient reason to investigate the projective methods.

Hammer (12) indicates several advantages of projective drawings. Those that are more appropriate for this study include simplicity of administration; useability with groups as well as with individuals; and the effectiveness of non-verbal techniques in use with children. Selltiz, Jahoda, Deutsch, and Cook $(13, p .285)$ enumerate many of the same advantages but add,

When the focus of an investigation is on the specific content of an individual's attitudes toward some social object, rather than on his general personality structure, the projective techniques designed for the study of personality are not very helpful. Yet a projective approach frequently seems desirable as a way of encouraging freedom and spontaneity of expression.

The advantages of the projective drawings were accepted as a general statement of their value. Specific techniques already developed to study personality were adapted to our purposes. The design for tho study used a subject-matter focus to structure the content of the pictures with the emphasis on group attitudes rather than individual characteristics.

The underlying assumptions of this study are: (I) projective drawings can be adapted to assess group attitudes; (2) drawings of 
policemen from three groups of second grade children can reveal feelings of the children toward policemen; and (3) the composite assessment of a given group of children will be indicative of the feelings of that group toward policemen.

The overall objectives of this study have a dual focus. One is to determine the group attitudes of children from three elementary schools toward police from projective drawings. The second is to assess the applicability of projectivo techniques in social work. Therefore, this study will provide data about children's attitudes toward policemen while at the same time evaluating the drawing techniques used to obtain the data.

\section{THE PROBLEM}

A popular assertion is that there is widespread Negro hostility toward the police. A typical statement of the situation is found in the Report of the National Advisory Commission on Civil Disorders (14, p.206).

Thus, to many Negroes police have come to symbolize white power, white racism and white repression. And the fact is that many police do reflect and express these white attitudes. The atmosphere of hostility and cymicism is reinforced by a widespread perception among Negroes of the existence of police brutality and cormuption and of a "double standard" of justice and protection--one for Nogroes and one for the white.

This conclusion has been based upon surveys of attitudes of minority groups toward police. "Negroes firmly believe that police brutality and harassment occur repeatedly in Negro neighborhoods. This belief is unquestionably one of the major reasons for intense Negro resentment against the police" (14, p.302).

Likewise, policemen indicate they aro disliked by Negroes. Bauma 
and Schode $(15,16)$ used a questionnaire to determine how police officers in two Michigan cities perceivod attitudes of inner city rosidents and Negroes in general toward police. The studies were conducted because of an awareness of increasing tension between police and residents and the lack of data on this problem (15). Tables I and II present two of their questions applicable to this study.

TABLE I

RESPONSES OF 120 KALAMAZOO AND 150 GRAND RAPIDS POLICE OFFICERS TO: "DO THE INNER CITY YOUTH FEEL THE POLICE ARE ALWAYS PICKING ON NEGROES?"

\begin{tabular}{lcc}
\hline & Kalamazoo & Grand Rapids \\
Response & $\%$ & 78 \\
\hline yos & 74 & 16 \\
no & 20 & 7 \\
not sure & 7 & 78 \\
\hline
\end{tabular}

TABLE II

RESPONSES OF 120 KALAMAZOO AND 150 GRAND RAPIDS POLICE

OFFICEIRS TO: "DO THE INNER CITY YOUTH THINK THAT

THE POLICE ARE UNFAIR IN THEIR TREATMENT OF DIFFERENT RACES, NATIONALTTIES, AND RELIGIOUS GROUPS?"

\begin{tabular}{lcc}
\hline Kesponse & $\substack{\%\\
}$ & Grand Rapids \\
\hline yes & 80 & 86 \\
no & 12 & 8 \\
not sure & 8 & 6 \\
\hline
\end{tabular}

The findings of both studies also indicato that $3 / 4$ of the police feel that attitudes of inner city residents have become more negative during 
the past ten years.

Raymond Momboisee (17, p.58) concludes from his experience with

minority groups in general,

One aspect of the sensitiveness and defensiveness of minority groups which is of special concern to the police is the fear and distrust of police which these groups generally have.... The result is that a minority member frequently regards the police officer as his mortal enemy.

A statement from the supplemental report to the National Advisory

Commission on Civil Disorders made by the Department of Social

Relations of John Hopkins University (18, p.14) reported that

The police saw the people in the ghetto, particularly adolescents and young adults, as hostile and uncooperative.... Only one in three believe Negroes regard policemen as friends, as compared to the three out of four who believe whites are friendly.

As a result of charges of brutality, Berson concludes (19, p.50)

Unlike white, middle-class children, Negro youngsters do not grow up thinking of the policeman on the corner as their friend. Most Negroes look upon the policeman as the brutal enforcer of the white man's laws--laws that have been used for three centuries to keep the black man down.

The attitudes of Negroes in Portland have not been thoroughly assessed. However, a statement in the Report of the Committee on Race and Education to the Board of Education, Multnomah County School

District No. 1 (20, p.49) indicates,

The Albina community image is unattractive for some who live in it and for those who observe it from the outside. Unfortunately, the attitude of som school porsonnel toward the community and its inhabitants roflects this imago. A double standard of behavior and expectation is applied.... Application of a double standard extends to other community agencies-health and sanitation problems, welfare incidence, delinquency, etc., are shrugged off with the comment, "What olse can you expect of these people?" Until quite recent years, we are persuaded, this attitude was particularly bad among those in charge of policing and prosecuting. Dope usage and even homicide were not punished because "Everyone knows that Negroes use dope," or "Everyone knows Negroes are violent." 
A study by DeJardin et. al (2l) of Negro and white boys entering the Portland area from a correctional school indicated a high degree of negativity toward police. There was a tendency for Negroes to be more negative than whites.

Widespread and intense dislike for police by Negroes would mean their children are exposed to these attitudes. Johnson, Johnson and Price-Williams (22) indicate that the social group with which a child is involved will produce in him reaction patterns which characterize most of the members of the group.

The presence of negative attitudes regarding police in young Negro children would have significance for three reasons: (1) it would tend to confirm the idea that thore is a dislike for police in Negro neighborhoods; (2) Negro children at an early age would be conditioned to view police unfavorably; (3) police community relations programs in Negro schools would not have significantly changed their image with the children. Also, the detection of negative attitudes in young children would suggest early prevention program development.

No studies which attempt to assess young children's attitudes toward police were found. Two studies were located that dealt with racial aspects of the problem. Neither attempted to use art as a data collecting method for research. Reiss (23) reports on a study with adults regarding police brutality. Thirty-six people observed policecitizen encounters in Boston, Chicago, and Washington, D.C., for seven days a week for seven weeks. The findings indicate the incidence of use of excessive force upon white citizens in encounters with the police is twice that for Negro citizens. An apparent fact was that all victims were offenders and from the lower class. Thus, if negative attitudes 
toward police are related to police brutality, there should be little difference between the lower Negro and lower white attitudes.

Portune (24) analyzed the attitudes of junior high school pupils toward police officers. He indicated "an examination of published and unpublished attitude studies of the past ten years has revealed no attitude research specifically devoted to juvenile attitudes toward police officers." The police officers he observed in Cincinnati felt that young childron were sympathetic and friendly, but adolescents were wary and hostile. All felt attitudes had changed toward the negative during the past fow years. Portune's general conclusions were that the overall attitudes of all groups of junior high school students were more favorable toward the police than unfavorable. The younger students were more favorable than the older. Girls were more favorable than boys. Whites were more favorable than Negroes. Although not conclusive there was some tendency toward more favorable attitudes among higher socloeconomic groups detected.

\section{GENERAL APPROACH}

Frisch and Handler (25) agree with Dennis (26) that children's drawings are useful in reflecting cultural values. The general problem for this study is: Do racial and/or socioeconomic factors influence how children draw policemen? If differences exist, does one group represent more negative attitudes toward police than others?

Mere observation might indicate pictures from one group differ from another. Yet, no conclusions about attitude could be made, since it might be that those of one background have had more practice in drawing and greater experience from which to draw. Therefore, some 
items from the personality projective techniques which connote emotion were used to measure differences. Hammer $(27, p .436)$ has devised a technique for assossing negative attitudes by having individuals draw minority group figures.

If people tend to take those traits or attributes which they cannot accept in themselves and as a defense, project them onto members of 2 minority group, then asking 2 subject to "draw a member of a minority group" may be expected to encourage the projection of the more negative and unconscious side of himself.

The same reasoning is the basis for the "Draw A Family Test." Therefore, this study used items of measurement from the projective literature generally acknowledged to indicate less favorable attitudes or emotions.

The overall hypothesis of this study is that Negro children's drawings of policomen will indicate more negative feelings than a simi-i. lar or a higher socioeconomic group of white children. Also, lower socioeconomic white children's drawings of policemen will indicate more negative feelings than a higher socioeconomic group of white children. The following eight hypotheses are advanced:

1. The distance between the self and the policeman will be greator in the drawings of Negro children than in the drawings of whit children of a similar sociocconomic background. Each of these groups will draw greater distance botween self and policeman than white childron of a higher soctoeconomic background.

2. The ratio of the size of the policoman to the size of the self will bo greater in the drawings of Negro children than in the drawings of white children of a similar socioeconomic background. Each of thase groups will draw a great ratio of size of policeman to size of 
self than will white childron of a higher socioeconomic background.

3. Negro children will draw policemen larger or smaller than white children of a similar socioeconomic background, and each of these groups will draw more extremes in size of policemen than white children of a higher socioeconomic background.

4. Negro children will draw fewer smiling policemen than white children of a similar socioecononic background, and each of these groups will draw fewer smiling policemen than white children of a higher socioeconomic background.

5. Negro children will have more omissions of body parts in their drawings of policemen than white children of a similar socioeconomic background, and each of these groups will have more omissions than white children of a higher socioeconomic background.

6. Negro children will draw policemen with larger hands than white children of a similar socioeconomic background and each of these groups will draw more large hands than white children of a higher socioeconomic background.

7. Negro children will place more weapons in their drawings than white children of a similar socioeconomic background, and each of these groups will draw more weapons than white children of a higher socioeconomic background.

8. Negro children will draw moro aggressive policemen than white children of a similar socioeconomic background, and each of these groups will draw more aggrossive policenen than white children of a higher socioeconomic background.

These eight hypotheses were derived from several different sources. These sources and the underlying rationale and scoring 
procedures for the hypotheses will be discussed in the following chapter. 


\section{CHAPTER II}

\section{METHODOLOGY}

\section{RATIONALE}

Most of the utilization of art by the social sciences has treated art as a diagnostic tool and as a projective technique. Art has been little used as a tool to assess group views and feelings. The majority of research in the field of children's art has revolved around the "Draw A Man" and "Draw A Person" tests, with lesser interest devoted to other projective techniques such as the "HTP" test (28).

Given the limited background work available to assist us in devising methods for evaluating group attitudes then, we adapted projective evaluation criteria, especially from Handler (29), Koppitz (30), Nachover (31), and Hammer (27), to develop techniques for analyzing our data. Our hypotheses were adapted from the projective literature, from our review of general literature dealing with racial problems and police brutality, and from the work of professionals such as Coles (32, 33). Lowenfeld (34), and Kellogg and O'DelI (35) who had experience in analyzing children's drawings on an individual basis but who had not developed general methods for assessing groups of drawings. From these three sources, eight hypotheses were developed and criteria for measuring each category were formalized.

Categories of judgment for our pictures, which had their basis in the projective literature included omissions, height of both policemen 
and self, and large hands. Nu merous authors working in the projective testing field have suggested that more anxious, hostile, withdrawn, or aggressive children omit body parts, draw very small or very large figures, and draw hands larger than faces. The results of several attitude surveys and Coles' (32) impressions of the drawings of Southern Negro children suggested to us that distance between the self and the policeman in the picture might be a significant deteminant of negative attitudes toward policemen. Several descriptive studies of children's art, notably Coles (32) and Dennis (26) have discussed the absence of smiling figures drawn by Negroes as an indicator of negative attitudes. The categories dealing with weapons and with aggressive policemen were formulated after reading the Riot Comission report (14) and numerous articles dealing with race relations and police brutality. While it was realized that any one of these items by itself would be inadequate to assess group attitudes toward policemen, it was hoped that a combination of different approaches drawn from a variety of areas might provide a start toward developing a methodology for assessing feelings through the use of children's art.

\section{SUBJECTS}

One hundred and fifty-two children from three Portland public grade schools participated. Two schools similar in income level were Buckman Grade School, a largely white school, and Humboldt Grade School, which is over 93 percent Negro. Both these schools have been designated as Model Schools. Model Schools is a Portland Public school educational enrichment progran for deprived areas. The upper middle class white school chosen was Ainsworth, an elementary school located 
in an older, high status Portland residential area in the West Hills. The most recent figures avallable list the Ainsworth school district median family income as $\$ 12,462$, the Buckman family median income, $\$ 4,494$, and the Humboldt family median income 44,983 . The Ainsworth median income is the second highest in the city school system. while the Buckman and Humboldt figures are the third and fifth lowest, respectively (36). The three comparison groups, then, were drawn from a lower middle class white area, a lower middle class Negro area, and an upper middle class white area. Sixty-eight Humboldt, 36 Buckman, and 48 Ainsworth second graders were used. While only two out of the three Buckman and Ainsworth second grades were involved, the total second grade population of Humboldt participated. The Buckman and Ainsworth principals were unable to arrange total second grade participation, but they did not feel there was any essential difference between the classrooms not participating and those involved in our study. The students from the three schools involved had participated in the police public relations program which included police visiting in the classrooms in the fall of 1967.

Second grade subjects were used. Iowenfeld (34) indicates children of this age have developed a definite concept of a human figure. There is a discovery of being a part of the environment, the child relates himself to others, and a relationship between color and object has developed.

\section{DATA COLLECIION}

Pictures from the three schools were collected during the third 
week of May, 1968. Conferences were held with each of the three principals, and a mimeographed instruction sheet (see Appendix B) was given to each of the teachers involved. Each child was furnished a I2" $x$ 18" sheet of smooth finish newspad paper, and restricted to the use of seven crayons: white, red, yellow, green, brown, blue, and black. Teachers were requested to write the topic "I MET A POLICEMAN IN MY NEIGHBORHOOD" on the blackboard and instructed to have each child draw and color a picture with this title. The instruction sheet cautioned the teachers to refrain from giving further instructions or discussing policemen with the class before or during the drawing period. Children were allowed as much time as necessary to complete the drawings. Identifying data for the pictures such as age, sex, race, and school were placed on the back of the pictures.

\section{ANALYSIS OF PICTURES}

After the criteria for judgment were developed a sample of pictures obtained from children of ages five through ten was used both to check agreement of the two judges and to refine scoring procedures. The final formulation of the judgment criteria is included in Appendix $A$ and was available for each judge to refer to throughout the scoring process.

Although 152 pictures were collected, only 129 of these were used in the final tabulation. Two pictures, one each from Humboldt and Ainsworth, were excluded because no human figure was represented. It was necessary to exclude the drawings of two Negro students in the Buckman group to maintain a homogeneous lower white socioeconomic sample. 
The other 19 pictures excluded represent one classroom from the Humboldt group which was atypical of the total sample. Although the teacher had followed our instructions, she had stressed the drawing of large, single figures with multi-colored backgrounds throughout the year, and the children in her class had been rewarded for drawing in this particular style. The total class drew figures which would be classified as abnormally large using Koppitz's criteria (30), backgrounds were drawn similarly with a multi-colored blunt overall shading, and several pictures were obvious copies of other drawings from the same classroom. Since these pictures seemingly represented a learned drawing pattern rather than displaying negative attitudes toward policemen, and because the divergence from the total sample was so great it would have biased the results, the total classroom was excluded from analysis. Although the topic was "I Met a Policeman in My Neighborhood," 52 out of the original 152 students drew only a policeman and excluded the self. Of these 52, 18 were from the atypical Humboldt class. HavIng excluded these 18, we were left with the problem of how to treat the remaining 34, who were equally distributed among the three groups. It was decided that an assumption that greater negative feelings lead to omission of self might be reasonable, but whether this was indeed the case or whether these 34 children simply did not respond correctly to the directions was inpossible to determine. It was decided then to simply omit these 34 from statistical analysis in testing hypotheses relating to distance between policeman and self, and ratio of height of policeman to height of self.

The pictures from the three schools were thoroughly mixed by a third party prior to judging. Judging was thus done without any 
background knowledge about individual pictures except that each picture came from the second grade of one of the three schools. Each judge independently scored twelve categories for each picture. The first eight categories correspond to the hypotheses: distance between self and policeman, ratio of height of policeman to height of self, height of policeman, smiles of policenan, omission of body parts of policeman, large hands of policeman, weapons in the picture, and aggressive policeman. The other four categories involved judgments of quality of drawing, number of colors used, and skin color of policeman and self. These four categories were intended only for descriptive purposes. The first three categories, distance between self and policeman, height of policeman, and height of self, were scored using a transparent plastic overlay inscribed with a millimeter grid. Measurements were done in millimeters. When the two scores for any picture differed by more than two millimeters, a third judge was used and the final score used was agreement of two of the three judgments. Scoring by the third judge was done independently and blind using the established judgment criteria. Cases involving a difference of one or two millimeters were resolved by using the midpoint of the two judgments. Scoring of smile of policeman, omission of body parts of policeman, large hands of policeman, weapons, and aggressive policeman was done on a plus-minus basis. Disagreements between the two judges in categories four through eight were resolved by obtaining a third judgment. The final score used was agreement of two of the three judgments. Body parts of policemen scored as omitted were taken from Koppitz's (30) study which tabulated the frequency of inclusion of body parts in the drawings of 1856 eight year olds, one-third of which was drawn from 
children from minority groups or lower socioeconomic background. Body parts drawn by 86 percent or more of these children included head, eyes, mouth, nose, trunk, legs, arms, and feet. A plus score on omissions meant that two or more of these body parts were omitted.

\section{STATIST ICAL PROCELURES}

The three groups were compared on hypotheses one through eight through chi square and median tests. The first two hypotheses involving millimeter scores were tested with a nonparametric median test. Hypothesis three, height of policeman, also involved millimeter measurement, but chi square analysis was used by applying Koppitz's (30) criteria for large and small figures to the scores. Chi square analysis was used to test hypotheses four through eight which dealt with presence or absence of judgment indicators. After tests of the individual hypotheses, the overall. study hypothesis was tested by means of chi square analysis, comparing the number of pictures in each group judged to have two or more negative indicators. In addition, chi square analysis was made of the sex differences in performance on each item. Mean age for each of the three groups was computed. Agreenent for each of the two sets of judgments was computed in terms of percentages for categories four through twelve. For each of the first three categories dealing with millimeter measurements, judgment agreement was assessed by performing a $\underline{t}$ test of the means of the two sets of scores.

The .05 level of probability was accepted as by convention. 


\section{CHAPTER III}

\section{FINDINGS}

\section{TESTS OF HYPOTHESES}

For convenience of discussion the upper socioeconomic white Ainsworth group will be referred to as group A, the lower socioeconomic white Buckman sample as group $B$, and the lower socioeconomic Negro Humboldt children as group $C$.

Tables III, IV, and V summarize the tests of the hypotheses. In these and the following tables, Negative $F$ indicates the number of pictures judged to show negative attitudes in each category. Total $N$ is the total number of pictures used for judgment in each category. Chi square tests throughout were one tailed with one degree of freedom and a critical value of 3.84 .

The first hypothesis stated that the greater the negative feelings the greater would be the distance between self and policeman in each group's drawings. It was expected that the greatest distance would be found in the group $\mathrm{C}$ drawings with a lesser distance shown in group $B$, and the smallest distance show in group $A$. The differences in group medians were tested comparing two groups at a time in the null form. Median tests comparing groups $A$ and $B, A$ and $C$, and $B$ and $C$ showed no differences in the distance between the self and policeman in the plctures. In all three cases the null hypothesis was accepted. Results of hypothesis one median tests follow on page 20. 
TABLE III

TESTS OF HYPOTHESES COMPARING GROUP B AND GROUP C

\begin{tabular}{lccccc}
\hline & \multicolumn{2}{c}{ Group B } & \multicolumn{2}{c}{ Group C } & Significant \\
Hypotheses & Negative & Total & Negative & Total & $\mathrm{X}^{2}$ \\
& $\mathrm{~F}$ & $\mathrm{~N}$ & $\mathrm{~F}$ & $\mathrm{~N}$ & values \\
\hline 1. Distance & 13 & 25 & 19 & 38 & \\
2. Ratio & 13 & 25 & 18 & 37 & \\
3. Height & 10 & 34 & 14 & 48 & \\
4. Smile & 13 & 34 & 24 & 48 & \\
5. Omissions & 21 & 34 & 16 & 48 & 5.50 \\
6. Hands & 0 & 34 & 0 & 48 & \\
7. Weapons & 4 & 34 & 19 & 48 & \\
8. Aggression & 2 & 34 & 2 & 48 & \\
\hline
\end{tabular}

TABLE IV

TESTS OF HYPOTHESES COMPARING GROUP A AND GROUP B

\begin{tabular}{lccccc}
\hline & \multicolumn{2}{c}{ Group A } & \multicolumn{2}{c}{ Group B } & Significant \\
Hypotheses & Negative & Total & Negative & Total & $X^{2}$ \\
& F & N & F & N & values \\
\hline 1. Distance & 18 & 37 & 13 & 25 & \\
2. Ratio & 19 & 37 & 12 & 25 & 4.60 \\
3. Height & 5 & 47 & 10 & 34 & \\
4. Smile & 11 & 47 & 13 & 34 & 19.18 \\
5. Omissions & 7 & 47 & 21 & 34 & \\
6. Hands & 0 & 47 & 0 & 34 & 5.37 \\
7. Weapons & 18 & 47 & 4 & 34 & \\
8. Aggression & 2 & 47 & 2 & 34 & \\
& & & & & \\
\hline
\end{tabular}


TABLE V

TESTS OF HYPOTHESES COMPARING

GROUP A AND GROUP $C$

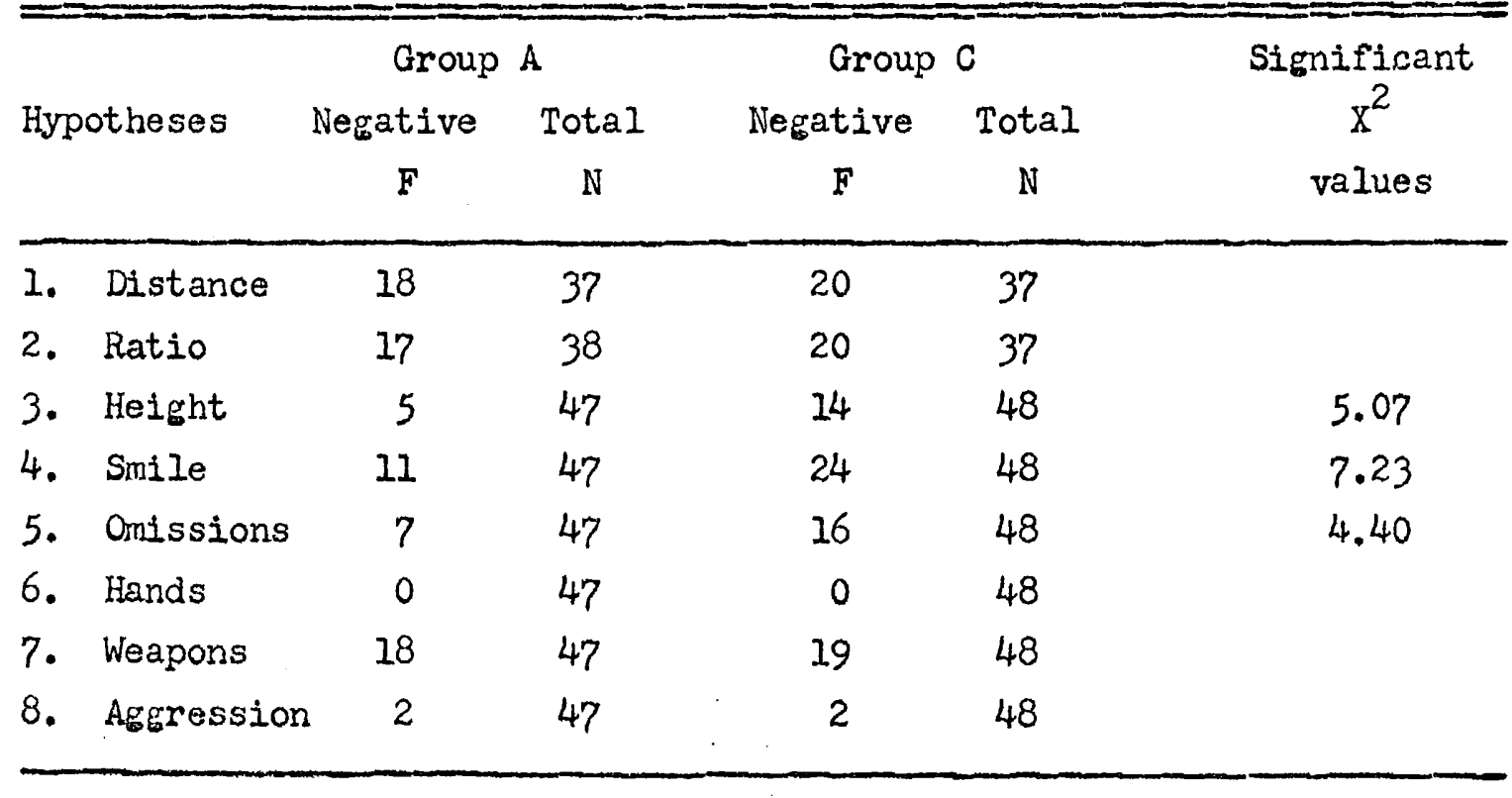

$$
\begin{array}{lll}
H_{0}: X \text { distance }_{A}=X \text { distance }_{B} & \\
X^{2}=0 & \text { I d.f. } & \text { p. }=>.05
\end{array}
$$

accept null hypothesis

$\mathrm{H}_{\mathrm{O}}: \mathrm{X}$ distance $_{\mathrm{A}}=\mathrm{X}$ distance $_{\mathrm{C}}$

$$
x^{2}=.01 \quad \text { Id.f. } \quad \text { p. }=>.05
$$

accept null hypothesis

$\mathrm{H}_{\mathrm{O}}: \mathrm{X}$ distance $_{\mathrm{B}}=\mathrm{X}$ distance $_{\mathrm{C}}$

$$
\mathrm{x}^{2}=0 \quad \text { ld.f. } \quad \text { p. }=>.05
$$

accept null hypothesis

Average distance between self and policeman was $61.8 \mathrm{~mm}$ for group C, $59.9 \mathrm{~mm}$ for group B, and $40.3 \mathrm{~mm}$ for group A. The distribution had a wide range and right skewness. Although these distances were in the predicted direction, they were not statistically significant. It was 
concluded, therefore, that hypothesis one showed no differences among the three groups in negative feelings toward policemen.

It was expected that the ratio of height of policeman to height of self in the drawings would be greater for children having more negative attitudes. As in the first hypothesis it was predicted that the largest ratio would be in group $C$ drawings, with a smaller ratio shown in group $B$, and the smallest ratio shown in group A. Raw scores of height of policeman were divided by raw scores of height of self, and the resulting ratio scores were tested.

Median tests comparing groups $A$ and $B, A$ and $C$, and $B$ and $C$ showed no differences in the ratio of height of self to height of policeman. The nuIl hypothesis was accepted for all three tests.

$$
\begin{aligned}
& \mathrm{H}_{\mathrm{O}}: \mathrm{X} \text { ratio }_{\mathrm{A}}=\mathrm{X} \text { ratio }_{\mathrm{B}} \\
& \begin{array}{lll}
\mathrm{X}^{2}=0 & 1 \mathrm{d.f} . & \text { p. }=>.05
\end{array} \\
& x^{2}=--\quad \text { ld.f. } \quad \text { p. }=>.05
\end{aligned}
$$

accept null hypothesis by observation

$$
\begin{aligned}
& \mathrm{H}_{\mathrm{O}}: \mathrm{X} \text { ratio }_{\mathrm{B}}=\mathrm{X} \text { ratio }_{\mathrm{C}} \\
& x^{2}=\ldots \quad \text { ld.f. } \quad \text { p. }=>.05
\end{aligned}
$$

accept null hypothesis by observation

Average ratio scores of height of self to height of policeman were 1.65 for group C, 1.58 for group B, and 1.48 for group A. Although these differences were in the predicted direction, they. were not statistically significant. It was concluded, therefore, that hypothesis two showed no differences among the three groups in negative feelings toward policemen. 
Hypothesis three postulated that the greater the negative fee1ings the more very large and very small policemen would be drawn. More extremes were predicted in the $C$ group, fewer in the $B$ group, and fewest in group A. Extremes were defined as smaller than $55 \mathrm{~mm}$ or larger than $230 \mathrm{~mm}$. These categories were adapted from Koppitz (30).

Chi square analysis was used to compare groups $A$ and $B, A$ and $C$, and $B$ and $C$. Although no significant differences were found between the number of extremes drawn by the $C$ and $B$ groups, chi squares were significant at the .05 level for groups $A$ and $B$, and $A$ and $C$. The $C$ and the $B$ groups drew more very small and very large policemen than group A.

$$
\begin{array}{lll}
H_{0}: \text { height extremes }_{A}=\text { height extremes }_{B} & \\
x^{2}=4.60 & \text { I d.f. } & \text { p. }=<.05
\end{array}
$$

reject nuIl hypothesis

$\mathrm{H}_{\mathrm{O}}$ : height extremes ${ }_{\mathrm{A}}=$ height extremes $\mathrm{C}$

$$
x^{2}=5.07 \quad \text { I d.f. } \quad \text { p. }=<.05
$$

reject null hypothesis

$\mathrm{H}_{\mathrm{O}}$ : height extremes $\mathrm{B}_{\mathrm{B}}=$ height extremes ${ }_{\mathrm{C}}$

$$
x^{2}=0 \quad \text { id.f. } \quad \text { p. }=>.05
$$

accept null hypothesis

There were 14 drawings of policemen less than $55 \mathrm{~mm}$ or larger than $230 \mathrm{~mm}$ in group C, 10 in group B, and 5 in group A. Although these differences were in the predicted direction, differences between groups $C$ and $B$ were not statistically significant. It was concluded, therefore, that hypothesis three showed that both group $C$ and group $B$ were more negative than group A.

Hypothesis four stated that the greater the negative feelings, the fewer sniling policemen would be drawn. More smiling policemen were 
expected in the A group, less in the B group, and fewest in the C group. Chi square analysis was used to compare the number of smiling policemen in each group. Chi square values were not significant at the .05 lovel for differences between groups $B$ and $C$, and $A$ and $B$. Differences in the number of smiling policemen drawn were significant at the .05 level between groups $A$ and $C$.

$$
\begin{aligned}
& H_{0}: \text { no smiles } A=\text { no } \operatorname{smiles}_{B} \\
& x^{2}=2.09 \quad \text { id.f. } \quad \text { p. }=>.05 \\
& \text { accept nuld hypothesis } \\
& \mathrm{H}_{\mathrm{O}} \text { : no smiles } \mathrm{A}_{\mathrm{A}}=\text { no smiles }_{\mathrm{C}} \\
& x^{2}=7.23 \quad 1 \text { d.f. } \quad \text { p. }=<.05 \\
& \text { reject null hypothesis } \\
& \mathrm{H}_{\mathrm{O}} \text { : no smiles } \mathrm{B}_{\mathrm{B}}=\text { no } \text { smiles }_{\mathrm{C}} \\
& \begin{array}{lll}
x^{2}=1.11 & 1 \text { d.f. } & \text { p. }=>.05
\end{array}
\end{aligned}
$$

accept null hypothesis

There were 24 policemen drawn without smiles in group C, 13 in group B, and 11 in group A. It was concluded that hypothesis four showed group $C$ more negative than group $A$, and that differences in negative feelings between groups $B$ and $C$, and $A$ and $B$ were not statistically significant.

Hypothesis five stated that the greater the negative feelings the more omissions would be included in drawings. More omissions were predicted in the $C$ group, fewer in the B group, and fewest in the A group. Chi square analysis showed significant differences in the number of omissions present between all three groups. The differences were not, howevor, all in the predicted direction since group $B$ showed the largest number of omissions. 


$$
\begin{aligned}
& \mathrm{H}_{\mathrm{O}} \text { : } \text { ondssions }_{\mathrm{A}}=\text { omissions }_{\mathrm{B}} \\
& x^{2}=19.18 \quad \text { Id.f. } \quad \text { p. }=<.05 \\
& \text { reject null hypothesis } \\
& \mathrm{H}_{\mathrm{O}} \text { : } \text { omissions }_{\mathrm{A}}=\text { omisions }_{\mathrm{C}} \\
& x^{2}=4.40 \quad \text { Id.f. } \quad \text { p. }=<.05 \\
& \text { reject nul]. hypothesis } \\
& \mathrm{H}_{\mathrm{O}}: \text { omissions }_{\mathrm{B}}=\text { omissions }_{\mathrm{C}} \\
& x^{2}=6.50 \quad \text { Id.f. } \quad \text { p. }=<.05
\end{aligned}
$$

reject nuIl hypothesis

There were 21 omissions in group B, 16 in group C, and 7 in group A. Since all differences were statistically significant, it was concluded that hypothesis five showed group B most negative, group C less negative, and group A least negative in feelings toward policemen.

Hypothesis six stated that the groater the negative feelings the greater the number of hands drawn larger than the face would be included in each group. More large hands were expected in the $C$ group, fewer in the B group, and least in the A group. This category did not discriminate, and no cases of hands drawn larger than the face were found in any of the drawings. This category was excluded from statistical analysis.

Hypothesis seven postulated that the greater the negative feelings the more weapons would be depicted by each group. The greatest number of weapons were predicted in the $C$ group, fewer in the $B$ group, and fewest in the A group. Chi square analysis showed significant differences between the $B$ and $A$ groups and between the $B$ and $C$ groups, but not in the predicted direction. The B group drew significantly fewer weapons than either of the other two groups, with the $C$ and A groups 
including an almost identical number of weapons in their drawings.

$$
\begin{aligned}
& \mathrm{H}_{\mathrm{O}} \text { : } \text { weapons }_{\mathrm{A}}=\text { weapons }_{\mathrm{B}} \\
& x^{2}=5.37 \quad \text { I d.f. } \quad \text { p. }=<.05 \\
& \text { reject null hypothesis } \\
& \mathrm{H}_{\mathrm{O}} \text { : } \text { weapons }_{\mathrm{A}}=\text { weapons }_{\mathrm{C}} \\
& x^{2}=.07 \quad \text { ld.f. } \quad \text { p. }=>.05 \\
& \mathrm{H}_{\mathrm{O}} \text { : } \text { weapons }_{\mathrm{B}}=\text { weapons }_{\mathrm{C}} \\
& x^{2}=5.96 \quad \text { Id.f. } \quad \text { p. }=<.05
\end{aligned}
$$

reject null hypothesis

Nineteen weapons were included in group $C$ drawings, 18 in group $A$, and four in group B. It was concluded that hypothesis seven showed group $B$ less negative than groups $A$ or $C$, and that differences in negative feelings between groups $A$ and $C$ were not statistically significant. The last hypothesis was that the greater the negative feelings, the greater the number of aggressive acts by policemen drawn by the groups. The greatest number was expected in the $C$ group, less in the $B$ group, and fewest in the A group.

Inspection revealed no significant differences between any of the three groups. There were two aggressive acts by policemen drawn by each group. It was concluded that hypothesis eight showed no differences in negative feelings toward policemen among the three groups. Significant differences were found between at least two of the groups in four of the eight hypotheses tested. As anticipated, the most extreme sizes of policemen were drawn by group $C$ and group $B$, with group A children drawing significantly fower extremes. The differences between the group $C$ and $B$ size of policemen was not significant, 
but since socioeconomic and racial factors were thought to play a part in negative feelings toward policemen, we would have expected differences between these two groups to be smaller than the differences between either of these compared to group A.

Differences observed in the number of smiling policemen in each group likewise are in agreement with the overall hypothesis. Group $C$ drew significantly fewer smiling policemen than the group A upper white socioeconomic group.

Difficulty in interpretation comes with the results of the omission and weapons categories. The lower white socioeconomic group had the largest number of omissions, with the lower Negro group drawing significantly fewer omissions, and the upper socioeconomic white group drawing the fewest omissions. Although the differences between the $A$ and $\mathrm{C}$ groups were in the predicted direction, we had no basis for anticipating that the $B$ group would draw the most omissions.

The same difficulty is posed by the weapons category result. Again the performance of the group $B$ children presents a problem of interpretation. This group drew fewer weapons than either the A or the $C$ groups, a result which would be interpreted in light of our hypothesis as indicating a more favorable attitude toward policemen than the other two groups.

There are at least two possible explanations for this unexpected result. One is that the weapons category does not discriminate negative attitudes and should be excluded if further research along these lines are done. A second possibility is that the differences observed Iie not so much with the children's attitudes toward policemen as with cultural factors related to drawing ability. It may be that lower 
socioeconomic children tend to include less detail of all kinds in their drawings, and if this is correct, it might be hypothesized that the $B$ group would draw not only more omissions but also fewer weapons and less detail of all kinds. Since this tendency would also apply to the Iower socioeconomic Negro group, their inclusion of weapons would assume even more significance as a reflection of negative attitudes toward police.

Because it was essential to be reliable in judging, more sophisticated judgment categories had to be sacrificed, but visual observation of the group B plctures compared to the group A pictures suggested that there were qualitative differences in the detail included and in the drawing ability which were not brought out by our judgment categories. The overall hypothesis for this study was that Negro children's drawings of policemen will indicate more negative feelings than drawings from either a similar or a higher socioeconomic group of white children. Lower socioeconomic white children's drawings of policemen will indicate nore negative feelings than drawings from a higher socioeconomic group of white children. An underlying assumption of this study was that a composite assessment of the drawings of a given group would be indicative of the group. In order to rank the pictures into categories of negativity for composite group comparisons, the criteria that determined a picture should be scored as negative in each of the eight categories already described were used. Each picture was given a score equal to the number of negative indicators it contained. Thus, a picture with a higher score was considered more negative than a picture with a lower score.

A larger percentage of group A children (27.7\%) drew pictures 
with no negative indicators compared to group B (11.8\%) and group C $(6.2 \%)$ children. A similar result appeared in the category where only one negative item was included in the picture. Forty percent of the group A drawings had one negative itern while 21 percent of group $B$ and 29 percent of the group $C$ drawings had one. Conversely, only 4 percent of the group A drawings had three or more negative indicators. Thirtytwo percent of group $B$ and 35 percent of group $C$ had three or more negative items. Table VI summarizes these measures.

TABLE VI

PERCENTAGE DISTRIBUTION OF THREE GROUPS BY NUMBER OF NEGATIVE INDICATORS IN PICTURES

\begin{tabular}{cccc}
\hline $\begin{array}{l}\text { Number Negative } \\
\text { Indicators }\end{array}$ & $\begin{array}{l}\text { Group A } \\
\text { Percent }\end{array}$ & $\begin{array}{l}\text { Group B } \\
\text { Percent }\end{array}$ & $\begin{array}{l}\text { Group C } \\
\text { Percent }\end{array}$ \\
\hline 0 & 27.7 & 11.8 & 6.2 \\
1 & 40.4 & 20.6 & 29.2 \\
2 & 27.7 & 35.3 & 29.2 \\
3 & 2.1 & 26.5 & 29.2 \\
4 & 2.1 & 2.9 & 6.2 \\
5 & none & 2.9 & 4.2 \\
\hline
\end{tabular}

The overall hypothesis postulated that group $C$ would be the most negative, group $B$ would be less negative, and group $A$ would be the least negative. Therefore, group C should contain a greater proportion of more negative pictures than either group $B$ or $A$ and group $B$ should have a larger proportion of negative pictures than group A. Chi square analysis based upon the number of pictures in each group with two or more negative indicators showed significant differences in the direction predicted between groups $A$ and $B$, and $A$ and $C$. There were no 
differences between group $B$ and $C$.

$$
\begin{aligned}
& \mathrm{H}_{\mathrm{O}} \text { : Negative indicators } \text { N }_{\mathrm{A}}=\text { negative indicators }_{B} \\
& x^{2}=10.10 \quad \text { Id.f. } \quad \text { p. }=<.05 \\
& x^{2}=10.14 \quad 1 \text { d.f. } \quad \text { p. }=<.05
\end{aligned}
$$

reject null hypothesis

$\mathrm{H}_{\mathrm{O}}$ : Negative indicators $\mathrm{B}_{\mathrm{B}}=$ negative indicators $\mathrm{C}$

$$
\begin{array}{lll}
x^{2}=.67 & 1 \text { d.f. } & \text { p. }=>.05
\end{array}
$$

accept null hypothesis

Group C contained 31 pictures with two or more negative indicators; group B, 23; and group A, 15. These differences were in the predicted direction but differences between groups $B$ and $C$ were not statistically significant. It was concluded, therefore, that group A showed significantly fewer pictures with two or more negative indicators, hence was less negative than group B or group C.

Results from the eight hypotheses tests would be inconclusive by themselves, taking into account the categories which did not discriminate and results not in the predicted direction. While scores on several items suggested trends that would indicate differences in the predicted directions, a number were not statistically significant. There were some tendencies which suggest that racial factors do play a part in children's drawings of policemen, notably in the smile and height categorles. Socioeconomic considerations were indicated by the omission results. Group A appeared to be different from groups B and C in several categories.

The comparison of the groups according to the proportion of 
negative pictures in each provided a confimation of the group differences. A picture was considered more negative if it contained a larger number of negative indicators. Group A contained a statistically significantly smaller proportion of negative pictures than either group $B$ or $C$ and was determined to be less negative. There was no difference between groups $\mathrm{B}$ and $\mathrm{C}$. The matrix pattem suggests that socioeconomic factors are predominant but that factors associated with race are also present.

\section{JUDGMENT AGREERMENT}

Scoring for the first three categories of distance, ratio, and height were done with a plastic grid quantified in millimeters. Although these measurements were more precise and less subjective than scoring of categories four through eight, judgment agreement was high throughout.

After both judges had scored distance between self and policeman for each picture, the mean and standard deviation for each set of judgments was computed. An $F$ test was completed to test the assumption of equal variance for the two sets of judgments, and a $\underline{t}$ test was performed on the two means. Results were as follows:

$$
\begin{array}{lll}
\bar{x}_{1}=54.11 \mathrm{~mm} & s_{1}=66.02 \mathrm{~mm} & \\
\bar{x}_{2}=54.18 \mathrm{~mm} & s_{2}=66.19 \mathrm{~mm} & \underline{t}=.091 \\
& &
\end{array}
$$

Differences between variances and between means were not significant at the .05 level, and were negligible in terms of absolute measures.

The same statistical procedures were followed to measure reliability of judgments for categories two and three, ratio of height of 
policeman to height of self, and height of policeman. The ratio score involved measuring both height of self and height of policeman and dividing the former into the latter. The measure of judges' agreement for this category, however, dealt only with judgments of height of self. Agreement for the ratio score would be somewhat different, but since $\underline{t}$ scores for both height of self and height of policeman were so low it was not felt necessary to deal any more extensively with category two than by comparing raw scores. Results for measurements of height of self, then, were as follows:

$$
\begin{array}{lll}
\bar{x}_{1}=72.12 \mathrm{~mm} & s_{1}=39.65 \mathrm{~mm} & \\
\bar{x}_{2}=71.80 \mathrm{~mm} & s_{2}=39.82 \mathrm{~mm} & \mathrm{~F}=1.01 \\
\mathrm{t}=.057
\end{array}
$$

Difference between the variances and the means was not significant at the .05 level, and was negligible in terms of absolute measures.

The following judgment agreement results for item three, height of policeman, were obtained:

$$
\begin{array}{lll}
\bar{x}_{1}=118.0 \mathrm{~mm} & s_{1}=80.80 \mathrm{~mm} & \\
\bar{x}_{2}=117.77 \mathrm{~mm} & s_{2}=80.74 \mathrm{~mm} & \underline{t}=.000
\end{array}
$$

Difference between the variances and the means was not significant at the .05 level, and was negligible in terms of absolute neasures.

Since categories four through eight were scored plus or minus for presence of smile, weapons, large hands, omissions, and aggression, a measure of reliability for these items was obtained by computing percentage of agreement between the two scores. Percentage of agreement for category four, smile of policeman, was 97.67 with three of the 129 judgnents being in disagreement. There were seven disagreements in 
judsment of omissions for a 94.5 percent acreement. Caterory seven, weapons, had three disagreements in judgments with 97.67 percent agreement. Category eight, aggression, also had three disagreements and a 97.67 percent agreement.

Category six, large hands, was excluded both from percentage of judgment agreement computation and from chi square ana.lysis since no pictures containing larger hands than heads were included in our sample. Judgment agreement for the two sets of judgments was above 94 percent for each of the eight categories and was considered satisfactory.

\section{ANALYSIS OF SEXUAL AND AGE DIFFTRENCES}

Our hypotheses assumed sexual differences did not play a part in children's attitudes toward policemen at this age, and chi square analysis was used to test this. In each category the null hypothesis was tested for sexual differences for each group. The only instance of a significant difference in male and female drawings was found in the number of Negro males who drew fewer smiling policemen compared to the number of female Negroes drawing smiling policemen. The chi square was 4.08 with 1 degree of freedom, significant at the .05 level. Comparison of the sexual differences of each group in each category yielded no significant differences except in the smile caterory mentioned above. The observed sexual difference in group $C^{\prime} s$ portrayal of smiling policemen cannot be explained on the basis of our study. Tables VII, VIII, and IX show comparisons for each category for the three groups by sex.

A final factor analyzed was the age of the three groups participating. When the mean age of each group was tabulated, the differences 
TABLE VII

COMPARISON OF ITEMS BY SEX FOR GROUP A

\begin{tabular}{|c|c|c|c|c|c|}
\hline \multirow[t]{2}{*}{ Hypotheses } & \multicolumn{2}{|c|}{ Male } & \multicolumn{2}{|c|}{ Female } & \multirow{2}{*}{$\begin{array}{c}\text { Significant } \\
x^{2} \\
\text { values }\end{array}$} \\
\hline & $\begin{array}{c}\text { Neg. } \\
\text { F }\end{array}$ & $\begin{array}{c}\text { Total } \\
\mathrm{N}\end{array}$ & $\begin{array}{c}\mathrm{Neg} . \\
\mathrm{F}\end{array}$ & $\begin{array}{c}\text { Total } \\
\mathbb{N}\end{array}$ & \\
\hline 1. Distance & 11 & 21 & 7 & 16 & \\
\hline 2. Ratio & 14 & 21 & 5 & 16 & \\
\hline 3. Height & 1 & 24 & 4 & 19 & \\
\hline 4. Smile & 6 & 24 & 5 & 23 & \\
\hline 5. Omissions & 4 & 24 & 3 & 23 & \\
\hline 7. Weapons & 9 & 24 & 9 & 23 & \\
\hline 8. Aggression & 1 & 24 & 1 & 23 & \\
\hline
\end{tabular}

TABLE VIII

COMPARISON OF ITENS BY SEX FOR GROUP B

\begin{tabular}{lccccc}
\hline Hypotheses & Male & \multicolumn{2}{c}{ Female } & Significant \\
& Neg. & Total & Neg. & Total & $\mathrm{X}^{2}$ \\
& & $\mathrm{~N}$ & $\mathrm{~F}$ & $\mathrm{~N}$ & values \\
\hline 1. Distance & 6 & 14 & 7 & 11 & \\
2. Ratio & 7 & 14 & 6 & 11 & \\
3. Height & 6 & 20 & 4 & 14 & \\
4. Smile & 9 & 20 & 4 & 14 & \\
5. Omissions & 13 & 20 & 8 & 14 & \\
7. Weapons & 4 & 20 & None & 14 & \\
8. Aggression & 2 & 20 & None & 14 & \\
& & & & & \\
\hline
\end{tabular}


TABLE IX

COMPARISON OF ITEMS BY SEX FOR GROUP C

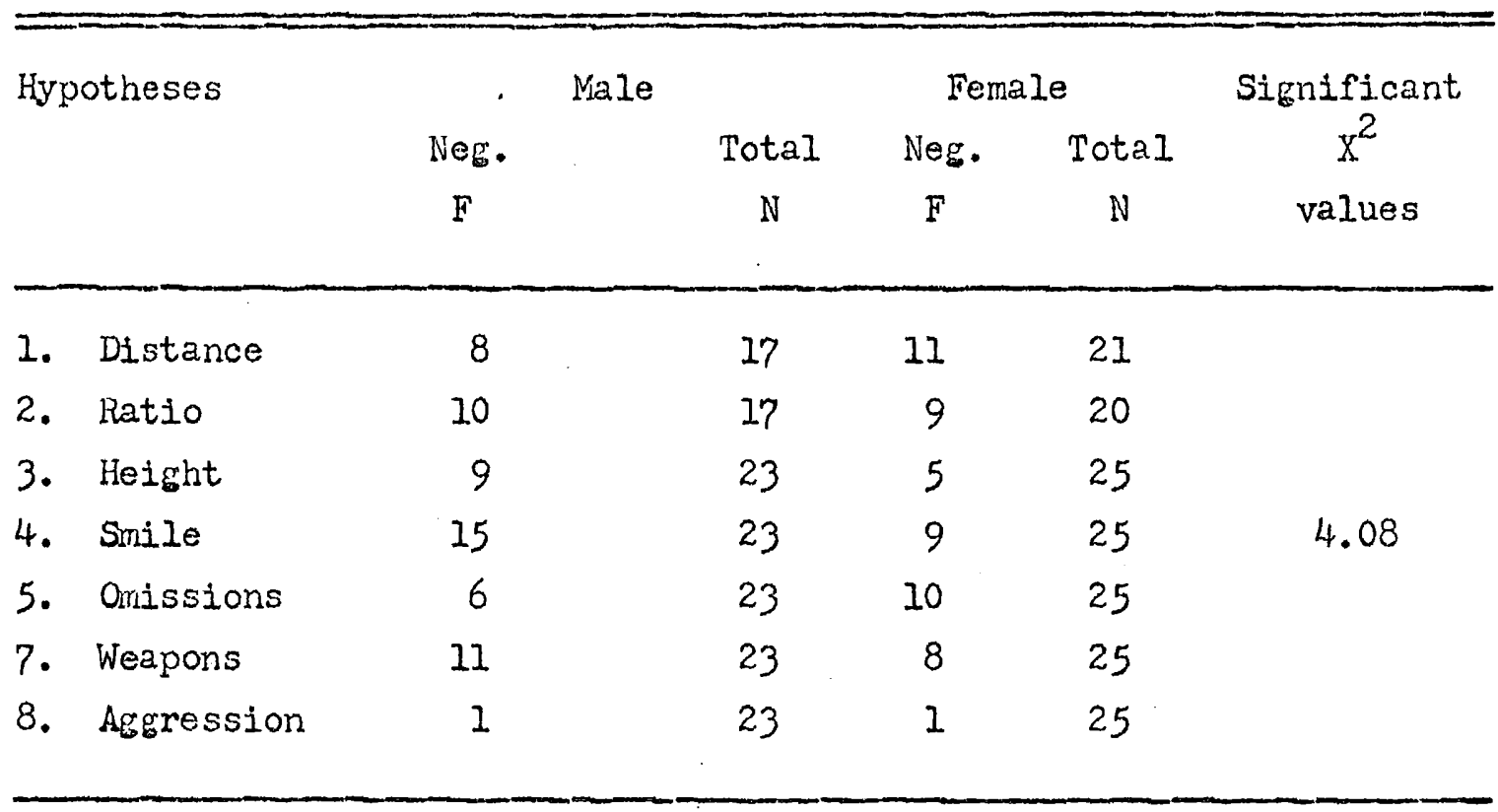

between the groups amounted only to a few days. Average age for the group A children was 8 years, .05 months; average for the group $B$ children was 8 years, .22 months; and for the group $C$ children 8 years, .05 months. The three groups, then, were approximately equal in terms of age.

\section{ANALYSIS OF ITEMS NINE THROUGH TWELVE}

In addition to testing the eight hypotheses, we computed the percentage of children in each group drawing Negro policemen and/or Negro selves, the number of colorsused by each group, and the quality of the drawings of each sroup.

Out of our reading in various areas which led to the formulation of the hypotheses, several other areas of interest developed. Although we did not wish to relate these areas to the overall hypothesis that 
there would be both a socioeconomic and racial difference in children's perception of policemen as revealed in their drawings, we did develop four additional judgment items to enable us to look at some other issues of interest.

It has been reported that Negro children infrequently draw either themselves of other figures as Negroes, depicting all humans in their pictures as white. The majority group, however, draw majority racial identity, and only rarely draw members of a minority group (26). Many of these observations were made before "Black Power" and "Black is Beautiful" thinking became important ghetto forces, we were interested in seeing whether the Negroes in our group would draw Black policemen and Black selves and also whether whites would draw exclusively white figures. Much analysis of children's art has also dealt with the number of colors used in drawing and this was another aspect of our sample we tabulated. A final subjective judgment by each judge about the quality of each drawing rated on a scale of 1 to 3 was made to attempt to determine whether we could observe qualitative differences among the three groups.

Over one-third, 18 out of 47 of group C students, drew Negro policemen, and one-fourth, 11 out of 47, drew Negro selves. This does not seem to reflect the tendencies for Negroes to draw only white figures mentioned earlier. None of the group B children, and only two of the group A, drew Negro policemen or Negro selves.

The number of colors available was fixed at seven, but a much larger percentage of group A children (93\%) used six to seven colors compared to the group B $(68 \%)$ and group C $(65 \%)$ children. The group B and group $C$ children appeared similar in the number of crayons used, 
as seen in Table $\mathrm{X}$.

\section{TABIE X}

NUMBER OF COLORS USED IN PICIURE OUT OF A MAXIMUM OF 7

\begin{tabular}{cccc}
\hline $\begin{array}{c}\text { Number of Colors } \\
\text { Used }\end{array}$ & $\begin{array}{c}\text { Group A } \\
\text { Percent }\end{array}$ & $\begin{array}{c}\text { Group B } \\
\text { Percent }\end{array}$ & $\begin{array}{c}\text { Group C } \\
\text { Percent }\end{array}$ \\
\hline $0-1$ & None & None & 2 \\
$2-3$ & None & 10 & 7 \\
$4-5$ & 7 & 22 & 26 \\
$6-7$ & 93 & 68 & 65 \\
\hline
\end{tabular}

The total number of children used here is 119, since any case involving disagreement between the two judges was excluded from comparison. This leaves a smaller number in each group for each of the last four categories, and these figures should be interpreted as being only suggestive of possible differences.

A rough attempt was made to judge the quality of each picture on a scale of 1 to 3, with 3 being the highest and 1 the lowest. Judgment agreement for this category was far lower than for any other, with 72.09 percent agreement. Again, since this was not related to our hypothesis a third judge was not obtained for pictures on which disagreements existed and these pictures were excluded from comparisons. The total number compared here is 93 . Groups $B$ and $C$ were judged to be similar, with 22 percent of group $C$ and 29 percent of group $B$ children judgred to have poorer drawings compared with only 8 percent of the group A children. Ninety-two percent of the group A children fell into the 
average and outstanding categrories, while only 78 percent of the group $C$ and 71 percent of the group $B$ children were so judged. Findings are summarized in Table XI.

TABLE XI

QUALTTY OF DRAWINGS

\begin{tabular}{lccc}
\hline Quality & $\begin{array}{c}\text { Group A } \\
\text { Percent }\end{array}$ & $\begin{array}{c}\text { Group B } \\
\text { Percent }\end{array}$ & $\begin{array}{c}\text { Group C } \\
\text { Percent }\end{array}$ \\
\hline Good & 8 & 0 & 3 \\
Average & 84 & 71 & 75 \\
Poor & 8 & 29 & 22 \\
\hline
\end{tabular}

Judgment agreement for categories nine through twelve are presented in Table XII.

TABLE XII

JUDGMENT AGREEMENTS FOR IIEMS 9-12

\begin{tabular}{lcc}
\hline Item & $\begin{array}{c}\text { Number of } \\
\text { Disagreements }\end{array}$ & $\begin{array}{c}\text { Percent } \\
\text { Agreement }\end{array}$ \\
\hline 9. Color of policemen & 4 & 96.89 \\
10. Color of self & 6 & 95.35 \\
11. Number colors used & 10 & 92.25 \\
12. Quality of drawing & 36 & 72.09 \\
\hline
\end{tabular}

Because judgments of number of colors used and quality of drawings involved a scaled rating system, these percentage of agreement scores do not show the direction or degree of the differences in judgments. 
Since these two items were not related to our overall hypothesis, we did not attempt a more sophisticated measure of agreement.

The analysis and interpretation of items nine through twelve are tentative. Taking this into consideration, however, the results of the last two categories suggest that the lower socioeconomic groups did include less detail, fewer colors, and produced a poorer quality of drawing. Until norms are more fully developed regarding differences expected in drawings of groups differing in socioeconomic and racial backgrounds, it is difficult to evaluate the factors involved in group differences such as were observed in this study.

\section{CONCLUSIONS AND IMPIICATIONS FOR FURTHER RESEARCH}

This study provided data from projective drawings about the group attitudes of children from three elementary schools. According to the findings of this study lower socioeconomic children, both Negro and white, are more negative in their drawings of policemen than higher socioeconomic white children. Since there was little difference between Negro and white children of the lower socioeconomic level, negativity in drawings of policemen seems to be related more to socioeconomic than racial factors. Group differences in sex and age were so small that they were not considered biasing factors.

This study presented several interesting problems. The interpretation of the topic, "I Met a Policeman in My Neighborhood," may have been too complicated for this age group. Approximately 22 percent of the drawings did not include a self in the picture. This created a problem of interpretation. Some clinicians would contend that an excluded self represented a negative feeling. However, for this study those 
drawings were excluded since the children drawing these pictures may have misunderstood the instructions. The two categories where measurement of the self was used indicated no significant differences among the groups.

It is not known how much the decision to exclude those pictures without a self rather than count them as more negative masked differences which may exist. However, the study could have been simplified to "Draw a Policeman" with instructions to draw a whole policenan, not a stick figure or a cartoon. This would reduce some of the detail but the elimination of whether the children understood the directions, the problem of which figure was the policeman, and the elimination of policemen draw in cars would be compensatory.

The measurements of height could have been refined. Considerable time was spent in measuring by exact millimeters. This could have been simplified by developing a plastic overlay with line markings at 0,50 , and 230 millimeters. The bottorn of the picture could be lined up with the 0 millimeter line. If the figure to be measured was over $230 \mathrm{milli}$ meters it would be scored large, and under 50 millimeters would have been scored small. This would save measurement time and reduce needless procedures.

Wuch of the time spent in this study involved the development and refinement of judging criteria. However, details and the more complex elements of the pictures were not measured. Also, the categories that were scored plus or minus may have been scaled to provide a more comprehensive view of the differences between the groups. If art is to be used on a more sophisticated basis, a methodology must be developed to judge and quantify more of the differences and detail in the pictures. 
Pretests are especially helpful if the researchers are not experLenced in the use of projectives and if sophisticated methods of analyzing the pictures are to be used. Techniques and procedures should be written down in a guide for judging and each rater given a copy of the criteria. Exclusive adherence to these areas and items listed is essential for good reliability.

The focus of this study on the attitudes of young children to determine whether racial and/or socioeconomic environments affect their feelings regarding police made it difficult to assess how accurately art reflects attitudes. Portune (24) concluded that older adolescents having had contact with police were more likely to be negative toward them than younger children. To obtain a more precise evaluation of projective drawings to assess groups, samples drawn from older groups would have been more appropriate. Groups with high probability of negative attitudes could be compared with those of low probability of negative attitudes according to race and/or socioeconoric factors. Such samples would reduce some of the uncertainty as to whether the results reflected attitudes or merely education, developmental, or skills.

The following conclusions regarding the use of projective drawings by social work are made from the experience of this study. As noted, the use of projective techniques involves considerable training and skill. The most proficient users appear to be clinical psycholom gists with yoars of experience. Yet, research has failed to support the validity of projective techniques. Some experts are remarkably accurate in their interpretations, but more research is needed.

A mere duplication of the developrnental or personality assessment methods being used by the other professions would not be 
justifiable. Yet, if the projective drawing techniques could be adapted and/or developed to measure environmental or culturaliy induced attitudes of selected groups regarding various specific foci, they would be valuable in social work's "simultaneous dual focus on man and environment."

The ease of administration of the drawing technique is appealing. The yield of data for the time invested is extensive. The possibilities of collecting research samples from distant geographic areas without expense or undue difficulties is an asset. Yet, the collection of data must be recognized as the most simple element of the projective techniques. The resources and time saved by the ease of administration are often expended in the complexity and difficulty of judging and interpreting the data. Validation is even more formidable.

Methods to obtain reliability of content judgments can be developed as demonstrated by this study. However, the reduction of judgment categories to simple objective measurements reduced the drawings' content to such simplification that much of the data's value was lost. A more effective plan would be to give judges sufficient training and/or experience so that more sophisticated details could be measured without loss of objectivity. Greater proficiency in analyzing more content of the drawings without reduction in reliability of judgments would give a better basis for social work to use projective drawings.

Even though ease of data collection and reliability of judgments were confirined by this study, the interpretations of the judgments were made with reservations. This was partially due to the lack of existing research and research methods dealing with the same focus and age group. But more important is the fact that projective drawings are enigmatic. 
The data obtained can be interpreted with equal reasoning in various ways. From this it is possible to conclude that projective drawings should not be used as a sole means of studying a problem. They may have a place as a rough screening device to obtain a general idea about a group on which to develop other exacting procedures for research.

The study sample, judgment criteria, and methodology were adequate for the purposes of this study. No attempt at validation was made. Howover, rosearch must validate the assumptions upon which this study was based before implications of the results can be accurately assessed. Two major areas for research are suggested: (1) can projective drawing techniques be adapted to reliably assess group attitudes, and (2) do the drawings of policemen reveal the children's true attitudes toward poljcemen.

If social work were to further explore the use of projective arawings, research snould precede the practitioner's use of the projective techntques. The popularity of these techniques has a tendency to exceed appropriate precautions. Also, the drawings and present criteria for evaluating them are ambiguous enough to allow those interpreting the data to find enough information to reinforce their use. Unless social work is going to make concerted efforts to thoroughly research and examine the value of projective drawings, no attempt should be made to use then for the purposes set forth in this study. 
SELECTED BIBLIOGRAPHY

1. Briar, Scott. "The Casework Predicament." Social Work, XIII (January, 1968), 5-11.

2. Turnor, John B. "In Response to Change: Social Work at the Crossroad." Social Work, XIII (July, 1968), 7-15.

3. Thomas, Edwin J., ed. The Sociombehavioral Approach and Application to Social Work. Now York: Council on Social Work Education, 1967. $110 \mathrm{p}$.

4. Hearn, Gordon, od. Contributiong toward an Holistic Concoption of Social Work: The Goneral Systems Approach. Unpublished manuscript, Council on Social Work Education, 1969. 113 p.

5. Crenshaw, David A., Suzanne Bohn, Marlene R. Hoffinan, John M. Mathews, and Stefan G. Offenbach. "The Use of Projective Nethods in Research: 1947-1965." Joumal of Projective Techniques and Personality Assessment, XXX.II (February, 1968), 3-9.

6. Mergaree, Edwin I., ed. Research in Clinical Assessment. New York: Harper and Row, 1966. $702 \mathrm{p}$.

7. Goodanough, Florence L. and Dale B. Harris. "Studies in the Psychology of Children's Drawings: II 1928-1949." Psychological Bulletin, XIVII (September, 1950), 369-433.

8. Handler, Ieonard and Joseph Reyher. "Figure Drawing Anxiety Indexes: A Review of the Iiterature." Journal of Projective Technjgues and Personality Assessment. XXIX (september, 1965), 305-313.

9. Swenson, Clifford N. "Ernpirical Evaluations of Human Figure Drawings. Psychologjeal Bulletin, LIV (Noverber, 1957), 431466.

10. Gordon, William E. "Basic Constructs for an Integrative and Generative Conception of Social Work." Contributions toward an Holistic Conception of Social Work: The General Systems Approach. Edited by Goldon Hearn. Unpublished manuscript, Council on Social Work Education, 1969. pp. 8-19.

11. Koppitz, Elizabeth M. and Vargaret de Noreau. "A Comparison of Emotional Indicators on Hunan Figure Drawings of Children from liexico and from the United States." Revista Interamericana de Psicologia, II (Marzo, 1968), 41-48. 
12. Hanmer, Tmanuel F. "Areas of Special Advantage for Projective Drawings." The Clinical Application of Projective Drawings. Edited by Emanuel F. Hammer. Springfield, Inlinois: Charles C. Thomas, 1958. pp. 391-438.

13. Selltiz, Claire, Viarie Jahoda, Morton Deutsch and Stuart W. Cook. Research Methods in Social Relations. New York: Holt, Rinehart, and Winston, 1967. $622 \mathrm{p}$.

14. Report of the U.S. National Advisory Commission on Civil Disorders, otto Kerner, Chairman. New York: Bantam, 1968. 609 p.

15. Bouma, Donald H. and Thomas V. Schade. "Police and Urban Unrest: A study of the Kalamazoo Police Department." Western Michigan University, 1967. (Mimeographed).

16. "Police, Riots, and the Inner City: A Study of the Grand Rapids Police Department." Western Michigan University, 1967. (Mineographed).

17. Momboisee, Raymond M. Community Relations and Riot Prevention. Springfield, Illinois: Charles C. Thomas, $1967.257 \mathrm{p}$.

18. "Riots." City, II (September-October, 1968), 12-14.

19. Berson, Lenora. Case Study of a Riot: The Philadelphia Story. New York: Institute of Human Relations Press, 1.966. $71 \mathrm{p}$.

20. Report of the Conmittee on Race and Education to the Board of Education, irultnomah County School District No. I, Jerbert $M$. Schwab, Chaiman. Portland, Oregon, 1964. 249 p.

21. DeJardin, Thomas W., Theresa F. Eubanks, Mary F. Hoyt, Steven J. Ickes, Carol W. Lane, David F. Staat. "Assessment of Subjective Experiences of Boys Entering the Community from a Correctional Schoo]." Unpublished Master's thesis, Portland State University, 1968. 79 p.

22. Johnson, Dale L., Carmen A. Johnson and Douglass Price-Williams. "Draw-a-llan Test and Raven Progressive Matrices Perfornance of Guatemalen, Maya and Iandino Children." Revista Interamericana de Psicologia, I (Junio, 1967), 143-157.

23. Reiss, Albert J. Jr. "Police Brutality--Answers to Key Questions." Transaction, V (August-Septernber, 1968), 10-20.

24. Portune, Robert G. "An Analysis of the Attitudes of Junior High School Pupils toward Police Officers Applied to the Preparation of a Work of Juvenile Fiction Catch Me If You Can, a Junior Novel." Unpublished Ph.D. dissertation, University of Cincinnati, 1965. $370 \mathrm{p}$. 
25. Frisch, Giora R. and Leonard Handiler. "Differences in Negro and White Drawings: A Cultural Interpretation." Perceptual and Motor Skills, XXIV (April, 1967), 667-670.

26. Dennis, Wayne. Group Values through Children's Drawings. New York: John Wiley and Sons, 1966. 211 p.

27. Hammer, Emanuel F. "Recent Variations of the Projective Drawing Techniques." The Clinical Application of Projective Drawings. Edited by Emanue.L F. Hammer. Springrield, Illinois: Charles C. Thomas, 1958. pp. 391-438.

28. Buck, John H. "The H.T.P. Technique." Journal of Clinical Psychology, V (January, 1949), 37-74.

29. Handler, Leonard. "Anxiety Indexes in the Draw-a-Person Test: A Scoring Manual." Journal of Projective Techniques, XXXI (June, 1967), 46-57.

30. Koppitz, Elizabeth M. Psychological Evaluation of Children's Hurnan Figure Drawings. New York: Grune and Stratton, 1968. $341 \mathrm{p}$.

31. Machover, Karen. Personality Projection in the Drawing of the Human Figure. Springfield, Illinois: Charles C. Thoinas, 1949. $181 \mathrm{p}$.

32. Coles, Robert. Children of Crisis. Boston: Little, Brown, 1967. $401 \mathrm{p}$.

33. XXXI (February, 1968), 1-15.

34. Iowenfeld, Viktor. Creative and Mental Growth. New York: The Macmillan Co., 1953. $408 \mathrm{p}$.

35. Kellogg, Rhoda and Scott O'Dell. The Psychology of Children's Art. New York: Randorn House, 1967. $107 \mathrm{p}$.

36. Committee on Race and Education, Herbert $\%$. Schwab, Chairman. "Wedian Incones of Families by School Area." Research Hemorandum of the Subcommittee on Youth Employment Qualifications and Opportunity. Portland, Oregon, 1964. pp. 72,73. (Mineographed). 
APPENDIX A

JUIGING CRITERIA

1. Distance

a. Heasure tollest policeman to self (self is closest figure)

b. Use grid, measurc horizontally in millimeters between two closest points of policeman and self

c. If no self, score $N$ on card

d. Include extensions of self and policeman (i.e., weapons, flower, etc.) in measurement

2. Ratio (measure height of self)

a. Closest person to tallest policeman is self

b. Exclude if self drawn in house (score $N$ on card)

c. Score if self jn car (see scoring procedure fur policeman in car below) and mark $C$ on card

3. Height (policeman only)

a. Measure in millimeters from bottom to top of policeman

b. If policeman enclosed in car, measure height of car--bottom of wheel to top of car--and add height of visible part of policeman. Score $C$ on card

c. If policeman enclosed in other object or house, score $\mathbb{N}$ on card.

d. Blue coats, hats, badges, identify policeman

e. If no determination of policeman is possible, take tallest figure and note on card with question mark

f. In exception to $d$., if one figure is in car and one out, assume the figure in car is policeman

g. When there are clearly two policeman, one in and one out of car, measure policeman out of car

4. Smile (policeman only)

a. Both corners of mouth turned up is smile--do not use other facial criteria to judge

b. Smile is judged minus on card

c. No mouth scored plus for smile (minus on card)

d. More than three sharp, pointed teeth not scored smile even if both corners turn up

e. Extend parallel line across lowest part of mouth, if corners extend up from this, score smile

5. Omissions (policeman only)

a. Score one omission for being in car (unless you can see whole body in car)

b. Omissions scored: arms (one or both), mouth, eyes, nose, head 
(note ears not omission), body, legs, feet (one or both legs and feet missing is omission)

6. Hands (policernan only)

a. Hand area includes from wrist out (i.e. line or beginning of curve for hand denoted wrist), if no wrist use line for sleeve

b. Score + if total estimated grid area for hand (one only) is larger than face. Judge largest hand. If questionable, count smaller squares within grid

7. Weapons

a. Judge entire picture

b. Weapon: guns, clubs, knives, handcuffs, holster-mo others

c. Disregard car: it is not a weapon

8. Obvious aggression (policemar only)

a. One hand or both raised above head

b. Gun, club, knife drawn or held in hand

c. Self and policeman handcuffed together

9. Skin color of policeman

a. Score + if policeman measured for height is Negro

10. Skin color of self

a. Score + if self measured for height is Negro

11. Colors used
a. $0-1$ color $=1$
b. $2-3$ colors $=2$
c. $4-5$ colors $=3$
d. $6-7$ colors $=4$

12. Quality
a. poor $=1$
b. average $=2$
c. very $\operatorname{good}=3$ 
APPENDIX B

INSTRUCTIONS:

As part of a research project dealing with children's images of policemen, we are asking your cooperation in obtaining drawings from the chilaren in your classroom. It is very important to the research design that no discussion of policemen take place until after the drawings are completed and that the children be given no additional instructions other than those printed here.

1. Each child is to have a white, red, Jellow, green, brown, blue and black crayon.

2. Each child is to have a $12^{\prime \prime} \times 18 "$ sheet of paper (furnished)

3. Print on the blackboard, "I NET A POLICEMAN IN MY NEIGHBORHOOD"

4. Read the following instructions to the class. Please do not interpret or add to the directions. You may repeat them as often as needed. "WOULD EACH OF YOU DRAW AND COLOR A PICIURE WITH THE TITLE 'I NET A POLICEMAN IN MY NEIGHBORHOOD." "

5. When finished, have the child write his name on the back and place in the folder provided with the appropriate room number. 


\section{APPENDIX C}

GROUP A PTCTURES

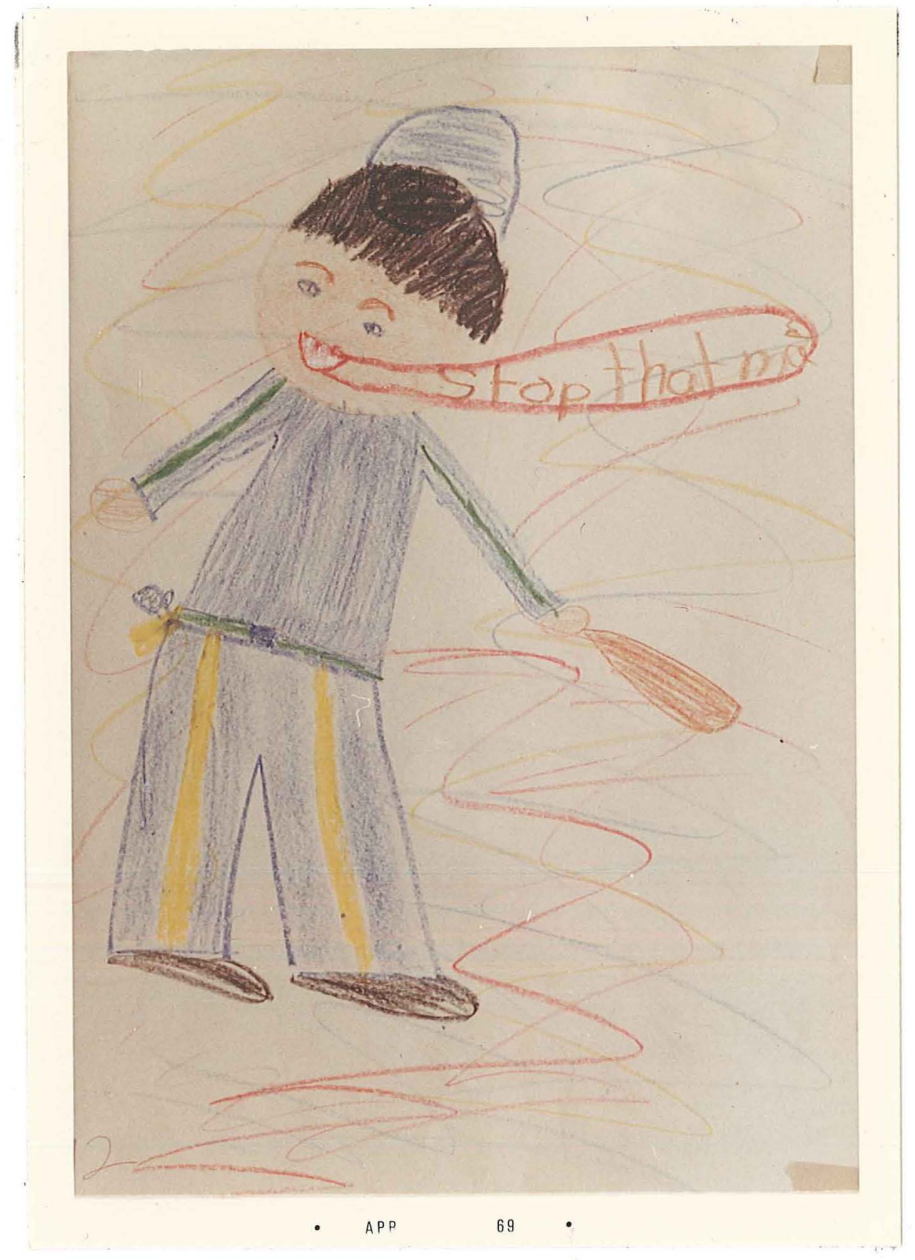



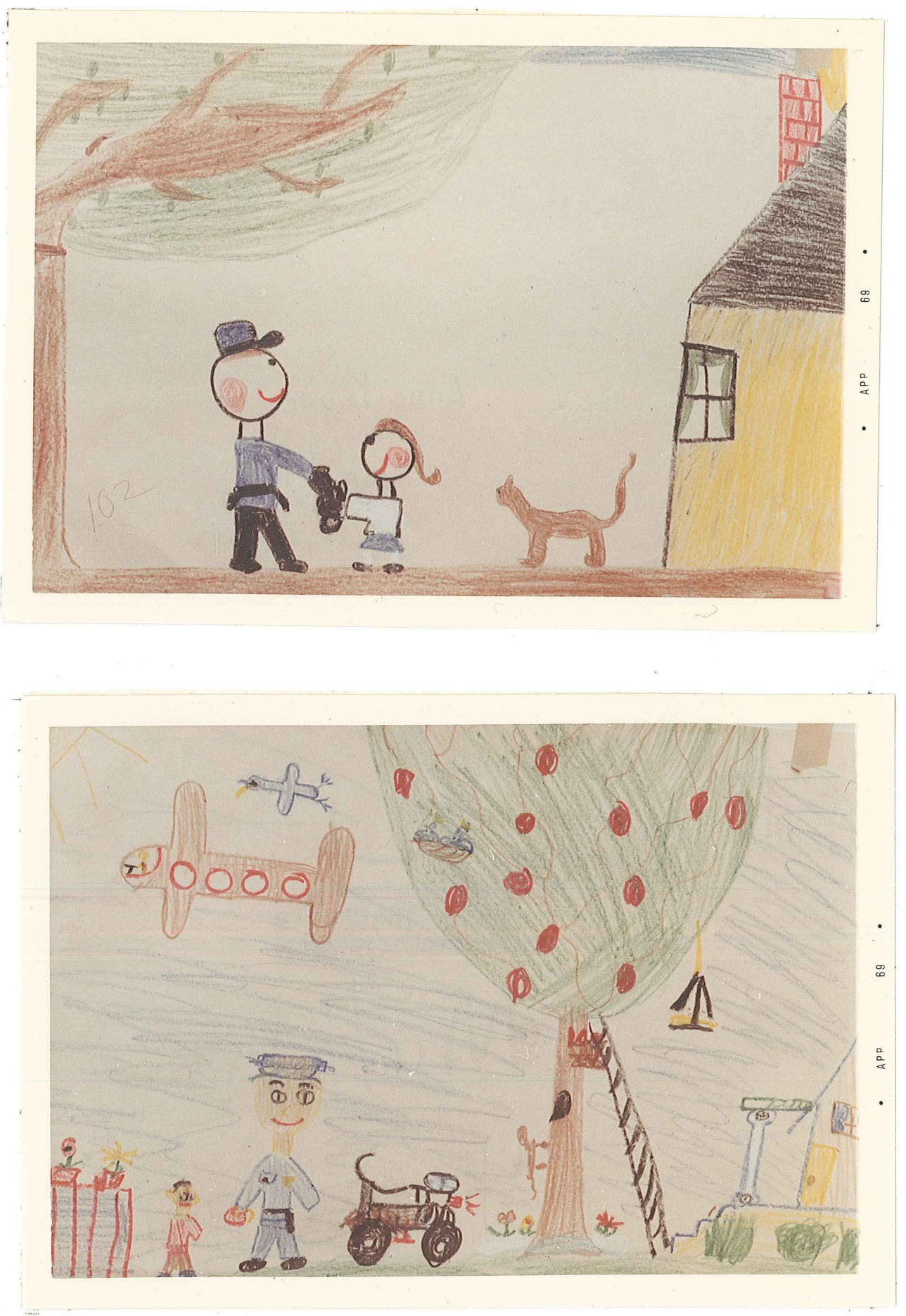


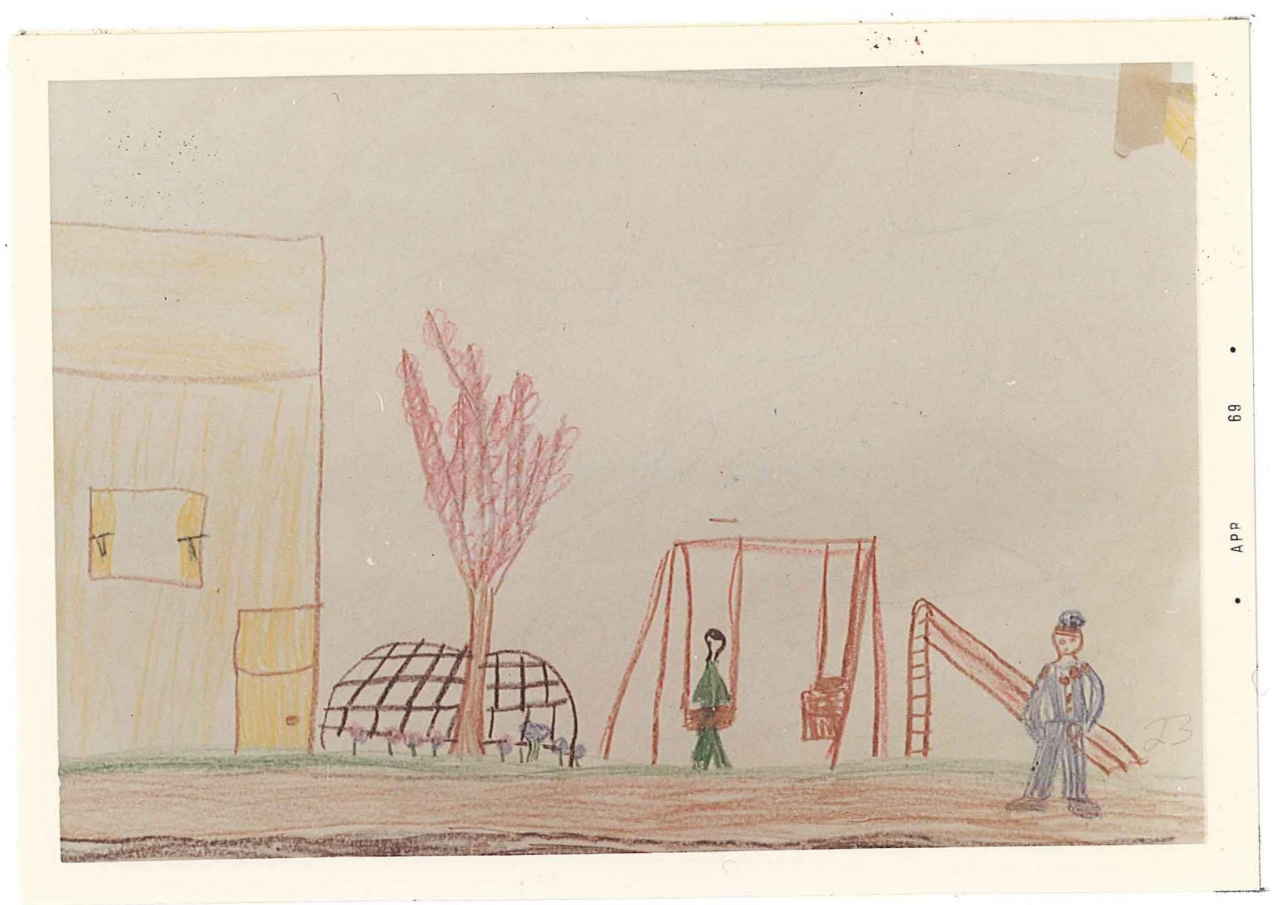

GROUP B PICTURES

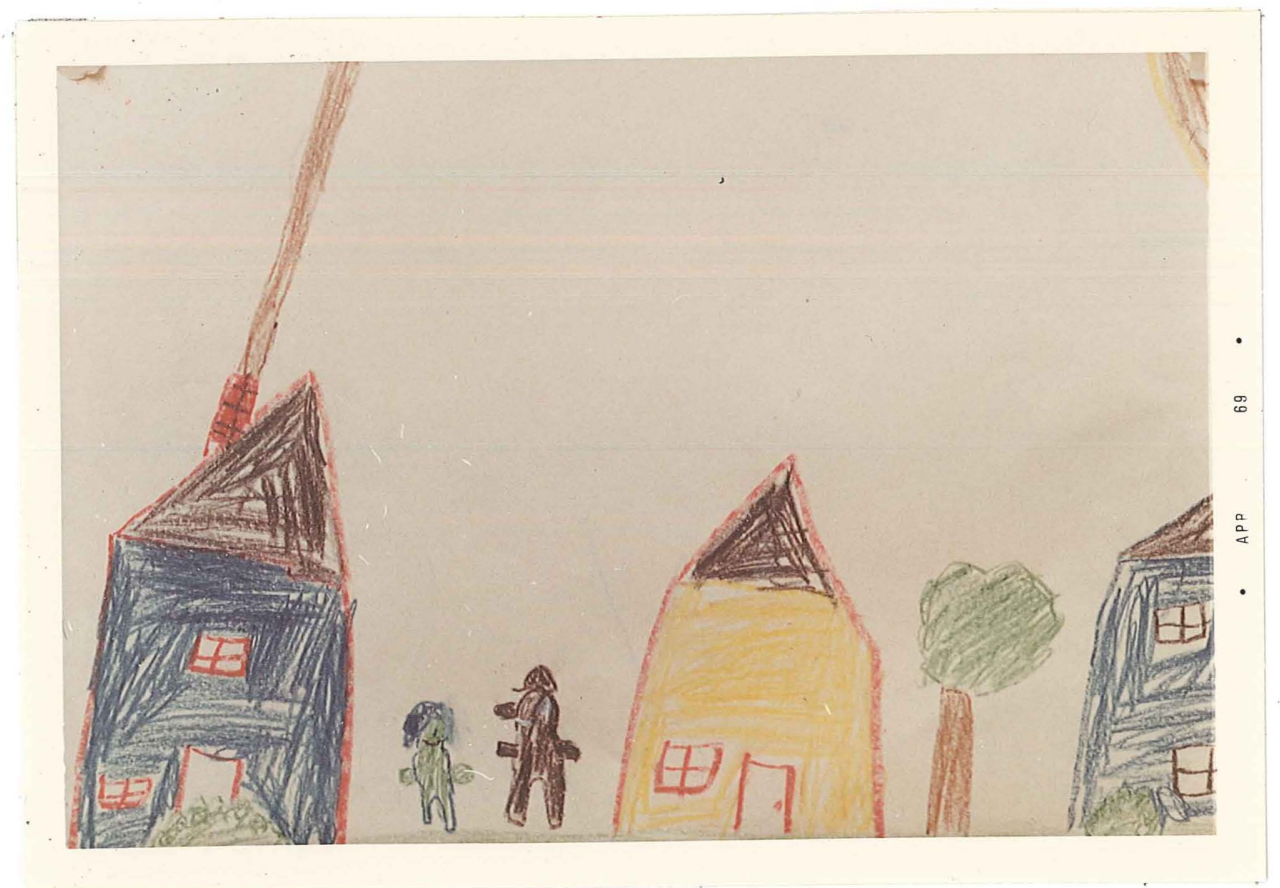



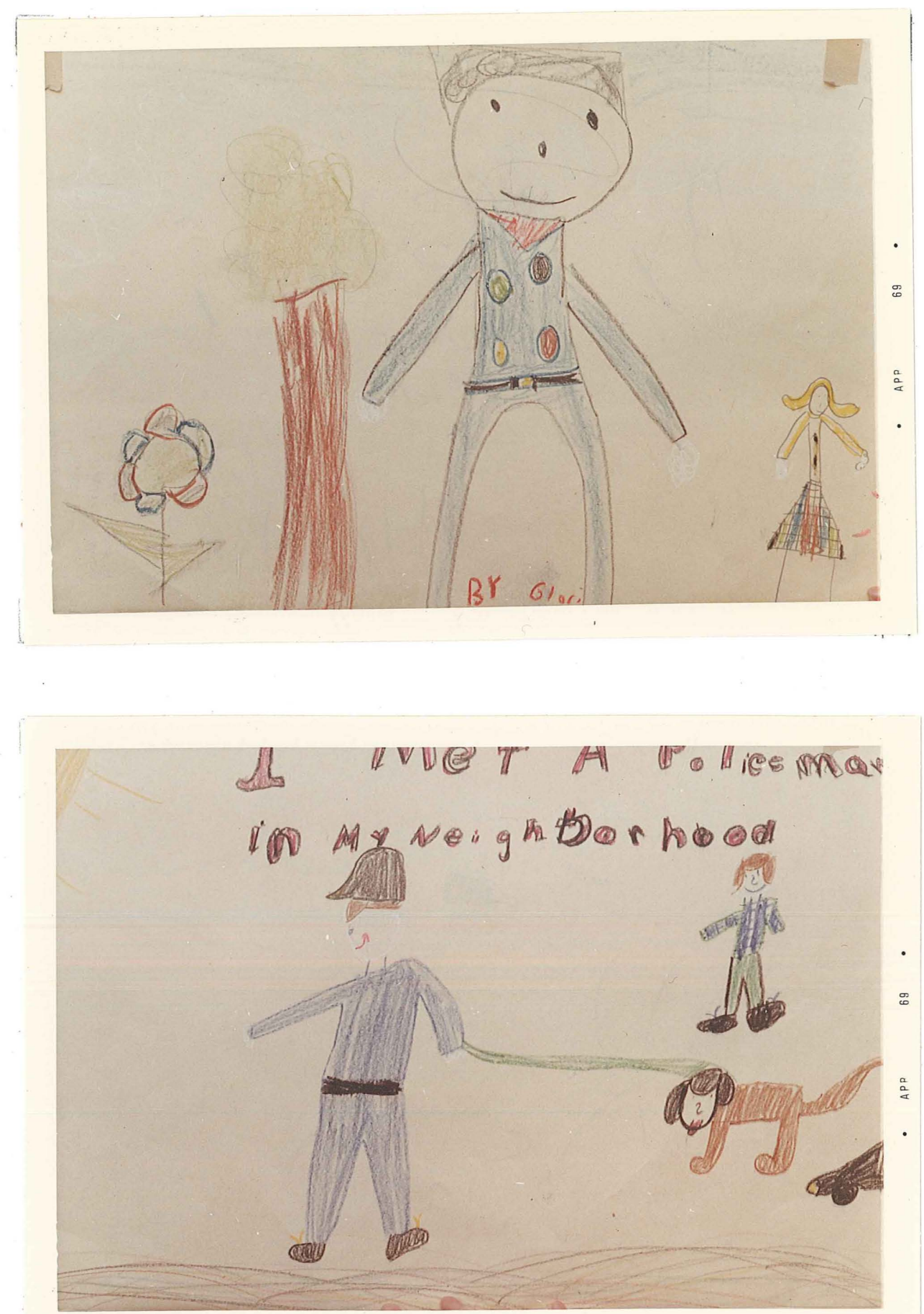


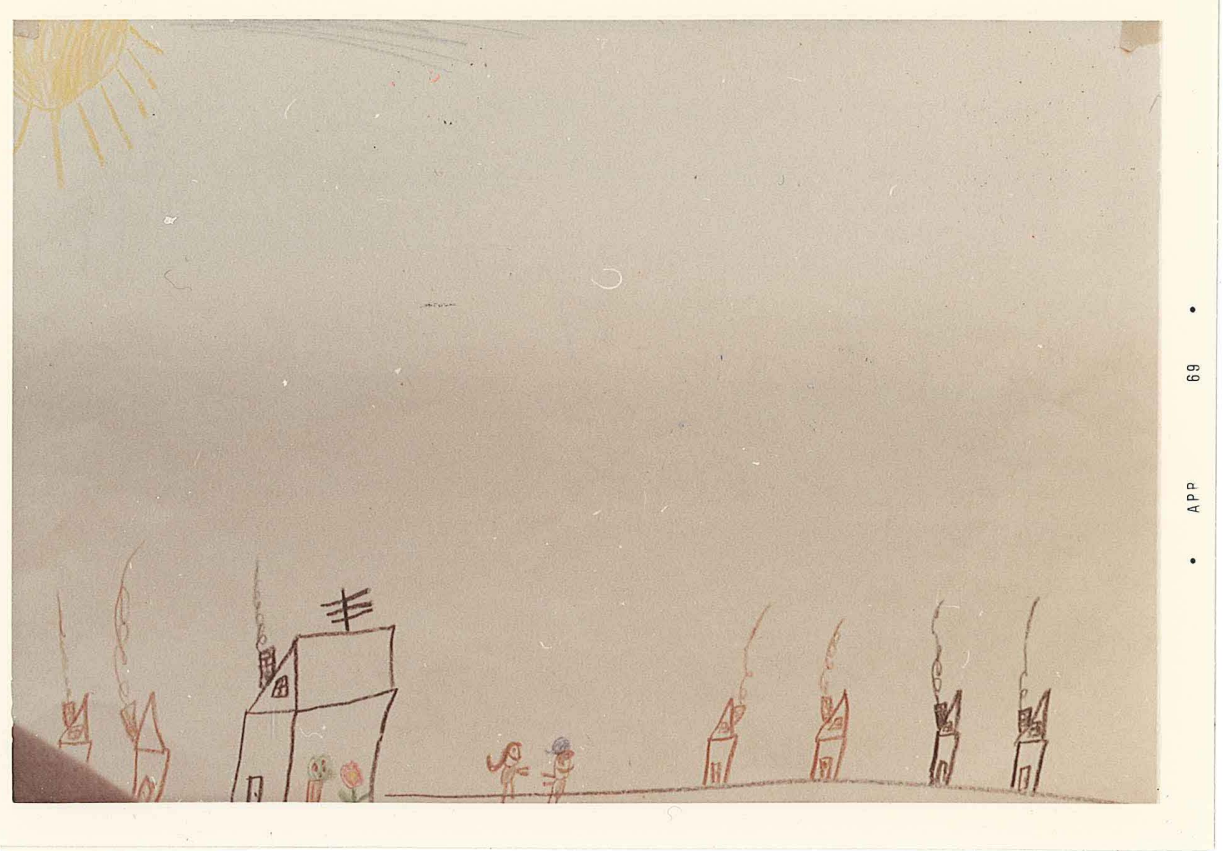

GROUP C PICTURES

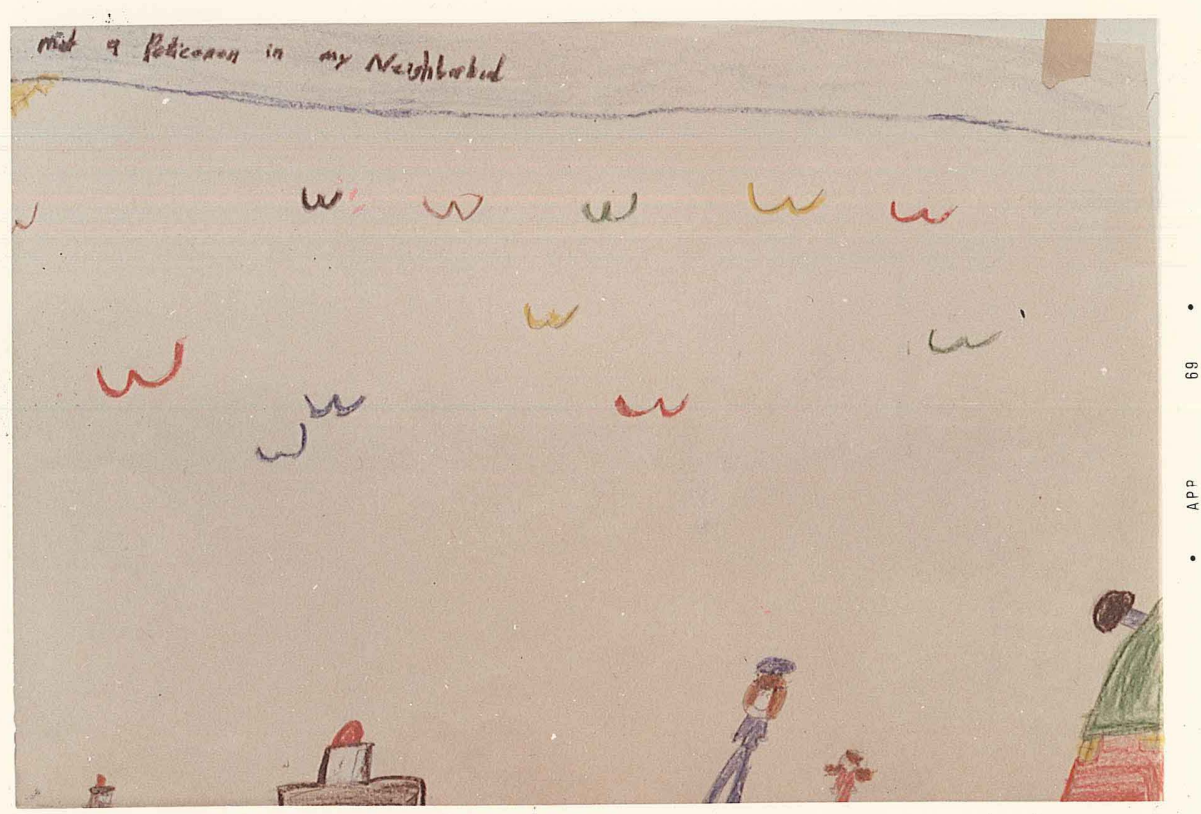



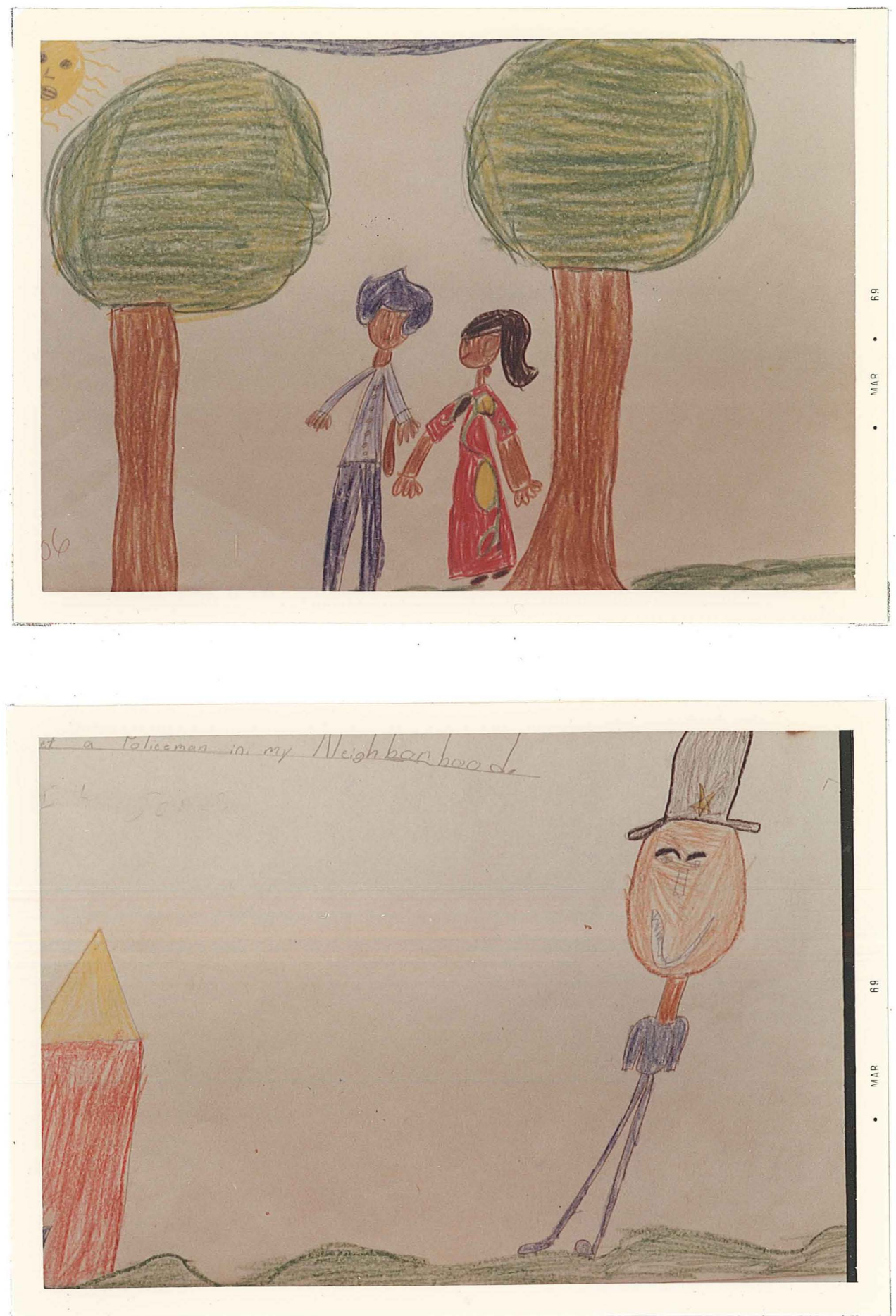


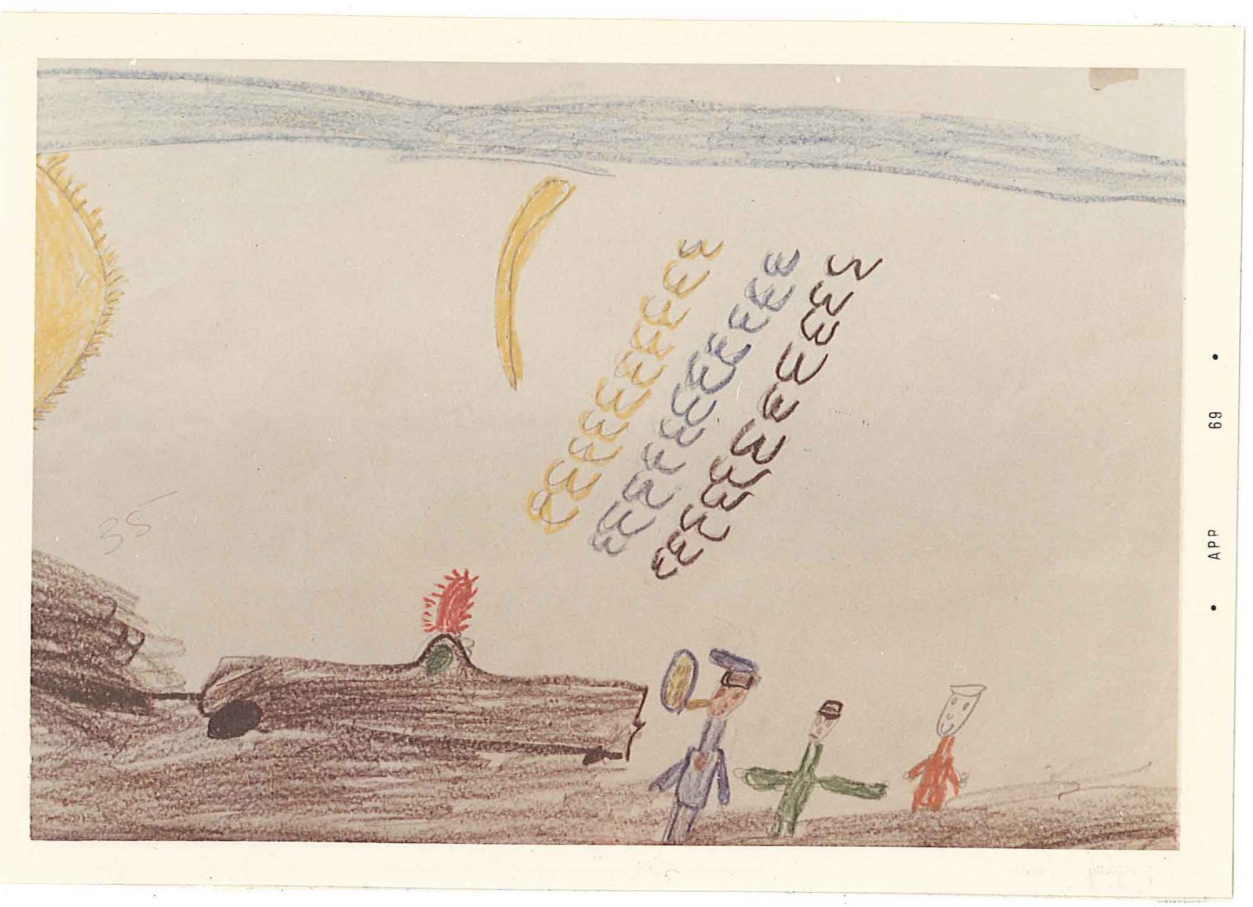

